\title{
A human kinase yeast array for the identification of kinases modulating phosphorylation-dependent protein-protein interactions
}

\author{
Stefanie Jehle ${ }^{1}$, Natalia Kunowska ${ }^{2}$, Nouhad Benlasfer ${ }^{1}$, Jonathan Woodsmith ${ }^{1,2}$, Gert Weber ${ }^{3,4}$, \\ Markus C. Wahl ${ }^{3}$, Ulrich Stelzl ${ }^{1,2,5}$
}

1 Otto-Warburg-Laboratory, Max-Planck-Institute for Molecular Genetics (MPIMG), 14195 Berlin, Germany

2 Institute of Pharmaceutical Sciences, University of Graz, 8010 Graz, Austria.

3 Institut für Chemie und Biochemie, Freie Universität, 14195 Berlin, Germany

4 Helmholtz-Zentrum Berlin für Materialien und Energie, Macromolecular Crystallography, 12489 Berlin, Germany.

5 Field of Excellence BioHealth - University of Graz and BioTechMed-Graz, 8010 Graz, Austria.

Correspondence: ulrich.stelzl@uni-graz.at

\begin{abstract}
Protein kinases play an important role in cellular signaling pathways and their dysregulation leads to multiple diseases, making kinases prime drug targets. While more than 500 human protein kinases are known to collectively mediate phosphorylation of over 290,000 S/T/Y sites, the activities have been characterized only for a minor, intensively studied subset. To systematically address this discrepancy, we developed a human kinase array in Saccharomyces cerevisiae as a simple readout tool to systematically assess kinase activities. For this array, we expressed 266 human kinases in four different Saccharomyces cerevisiae strains and profiled ectopic growth as a proxy for kinase activity across 33 conditions. More than half of the kinases showed an activity-dependent phenotype across many conditions and in more than one strain. We then employed the kinase array to identify the kinase(s) that can modulate protein-protein-interactions (PPIs). Two characterized, phosphorylation-dependent PPIs with unknown kinase-substrate relationships were analyzed in a phospho-yeast two-hybrid assay. CK2 $\alpha 1$ and SGK2 kinases can abrogate the interaction between the spliceosomal proteins AAR2 and PRPF8 and NEK6 kinase was found to mediate the estrogen receptor (ER $\alpha)$ interaction with 14-3-3 proteins. The human kinase yeast array can thus be used for a variety of kinase activity-dependent readouts.
\end{abstract}

199 words 
bioRxiv preprint doi: https://doi.org/10.1101/2021.11.18.469002; this version posted November 19, 2021. The copyright holder for this preprint (which was not certified by peer review) is the author/funder, who has granted bioRxiv a license to display the preprint in perpetuity. It is made available under aCC-BY-NC 4.0 International license.

\section{Introduction}

Protein kinases represent one of the largest protein families in eukaryotes, with the 518 annotated human kinases comprising about $2 \%$ of the protein coding genome [1,2]. The kinase domain catalyzes the phosphorylation of mainly serine, threonine and tyrosine residues. Already, over 290,000 phosphorylation sites in human proteins have been reported (phosphosite.org; 09/21). Phosphorylation of a protein can have a wide range of molecular effects, such as changes in activation status, conformation, localization, or interaction patterns. Phosphorylation underpins cellular signaling pathways and regulates diverse processes such as transcription, metabolism, the cell cycle, and proliferation. Consequently, dysregulated protein kinases often drive disease phenotypes, and elucidating kinase activity profiles [3], their substrate relationships [4-6] and their effects on cellular processes and phenotypes [7] is imperative to better understand the mechanisms of disease progression. Multiple kinase inhibitors are used as first line therapy in many cancers as well as in other diseases [8]. Despite the large number of human kinases with a pivotal role in cellular signaling, there is a welldocumented research bias towards a small set of highly-studied kinases such as p38a, SRC, EGFR, PKA, ERK1, KDR, ABL, CDK1 or KIT [9,10]. Studying kinase activity within cells is difficult, as kinases exhibit overlapping substrate specificity and differential expression, depending on the cell type, cell cycle phase, or subcellular localization, and have order(s) of magnitude differences in enzymatic activities. Furthermore, kinases form complex signaling networks that contain redundancy and feedback loops. Therefore, assaying kinase activity is typically done with purified kinase domains in vitro or with engineered biosensors [11-14]. However, a versatile simple readout to analyze wild type kinase activities in parallel at the kinome scale would be a valuable complement to current approaches.

Human kinases have been shown to be active in yeast. For example, expression of human serine/threonine (S/T) cell cycle kinase CDK1 suppresses lethality of $c d c 28$ kinase mutant alleles in yeast $[15,16]$. The yeast kin2 8 deletion strain could be complemented by seven human paralog kinases [17]. Also active tyrosine (Y) kinases have been expressed in yeast to reveal kinase regulation mechanisms [18], identify protein-protein interactions [19] and study mechanism of kinase specificity [5]. Elevated expression of active human kinases quickly causes yeast growth defects. When expressing v-SRC, yeast growth was diminished [20-23] and later reports confirmed that human protein tyrosine kinase toxicity in yeast can be explained by aberrant phosphorylation of yeast proteins [24-26]. Likewise, when human S/T kinase AKT1 is expressed in yeast it is phosphorylated on T308 and S473 and thus activated [27]. When AKT1 activity is increased either through oncogenic mutations or coexpression of the catalytic subunit of PI3 kinase, it causes increased growth inhibition of yeast cells [28]. In order to set up a drug screening platform in yeast, Sekigawa et al. utilized a human cDNA library which also contained human kinases for overexpression screening. About $23 \%$ of the tested kinases, including serine/threonine kinases, caused a visible growth defect of yeast under standard growth conditions [29]. Recently, screening of $>500$ human kinases revealed 28 kinases with strong 
bioRxiv preprint doi: https://doi.org/10.1101/2021.11.18.469002; this version posted November 19, 2021. The copyright holder for this preprint (which was not certified by peer review) is the author/funder, who has granted bioRxiv a license to display the preprint in perpetuity. It is made available under aCC-BY-NC 4.0 International license.

Kinase array, 11/18/2021

overexpression-associated toxicity in yeast, that was further leveraged to screen for genetic suppressors of this growth defect [30].

Here, we aimed to systematically exploit the yeast growth phenotype caused by overexpression of active human kinases as an activity readout. While $15 \%$ of the 6100 S. cerevisiae genes are essential under standard growth conditions, approximately another $63 \%$ of the $S$. cerevisiae open reading frames (ORFs) were required for full growth when tested under more than 1000 different conditions [31]. In addition, essentiality of $S$. cerevisiae genes is strongly dependent on genetic interactions, which vary within different genotype of the strains [32]. This can be explained by the cellular protein interaction networks underlying the genotype to phenotype relationship, which are strongly modulated through genetic and environmental variation $[33,34]$. Therefore, we hypothesized that the deleterious effects of aberrant phosphorylation of yeast proteins by human kinases may be further enhanced under non-standard culture conditions and in different genomic backgrounds of different S. cerevisiae yeast strains.

We developed a human protein kinase yeast array that comprises more than $50 \%$ of the annotated human kinome and utilizes ectopic yeast growth as a simple readout for kinase activity in a living organism. Yeast growth is assayed with four strains with different genomic backgrounds and across a large variety of environmental conditions. Kinase activity is demonstrated growth assays in comparison with kinase-dead mutant versions and by assaying phosphorylation of yeast proteins directly with different phospho-substrate antibodies on whole yeast protein lysates. The yeast array is a versatile tool to broadly capturing human kinase activity which can be coupled to any yeast assay available. Here, we demonstrate its utility by applying the array in identification of the kinases modulating known phosphorylation dependent PPIs.

\section{Results}

An array of human protein kinases in budding yeast

To construct a large human kinase array in yeast and leverage yeast growth phenotypes as kinase activity readout under various conditions and different genetic backgrounds, we collected ORFs for 266 human protein kinases (Figure 1A). As a control group for the kinases, we employed 80 proteins, including 10 kinase-dead versions and 70 unrelated proteins without kinase domains. $92 \%$ of the proteins in the kinase set and control set were covered with two or more ORFs. We subcloned the ORFs into two yeast expression vectors, both under a weak $\mathrm{Cu}^{2+}$ inducible yeast promoter, either with or without a nuclear localization sequence [5,19], arriving at a total of 1017 different plasmids. The 266 protein kinases represented over a half of the known human kinome from all major groups and families of the Human Kinome Tree [2] (Figure 1B).

The basic underlying principle of our kinase yeast array approach is that kinase activity will lead to aberrant phosphorylation of yeast proteins and thereby impair the yeast growth. In an initial test, the induction of kinase expression at $20 \mu \mathrm{M} \mathrm{Cu}^{2+}$ resulted a yeast growth phenotype for $18 \%$ of the kinases. To be able to assay kinase activity using growth phenotypes as broadly as possible, we used four $S$. 
bioRxiv preprint doi: https://doi.org/10.1101/2021.11.18.469002; this version posted November 19, 2021. The copyright holder for this preprint (which was not certified by peer review) is the author/funder, who has granted bioRxiv a license to display the preprint in perpetuity. It is made available under aCC-BY-NC 4.0 International license.

Kinase array, $11 / 18 / 2021$

cerevisiae strains with different genomic backgrounds exhibiting different protein expression and growth phenotypes: the commonly used haploid laboratory strain BY4742 (MAT $\alpha$ ) [35,36], the haploid yeast two-hybrid (Y2H) strain L40c (MATa) [37,38], the diploid strain W303 (MATa/MAT $\alpha$ ) [39], and the haploid protein expression strain Y258 (MATa) [40]. They were individually transformed with the two sets of kinase plasmids. We then cultured these strains in parallel in 384-array format on agar under various growth conditions (Figure 1A). The conditions included carbon sources other than glucose, the presence of detergents or denaturing agents, environmental triggers ( $\mathrm{pH}$, temperature), and addition of metal ions, osmotic stress agents, and other chemicals (such as $\mathrm{MnCl}_{2}, \mathrm{~K}_{3} \mathrm{Fe}(\mathrm{CN})_{6}$, or $\mathrm{LiCl}$ ) to the growth media. Together, 33 unique treatments were assayed with additives in various concentrations adding up to a total of 73 different conditions in which at least one of the four strains were evaluated successfully (Supplementary Table 1). The evaluation of over 300,000 yeast spots for 266 kinases revealed that many kinases show growth reduction in at least one condition for one strain. Growth was evaluated on a 0-3 scale, reflecting none, weak, moderate, to severe growth reduction, respectively. Conditions which reduced growth of more than 175 (17\%) colonies were excluded from further analysis. A total of 243 condition-strain pairs were considered, with 41 conditions evaluated for all four strains and a total of 70, 62, 64, and 47 conditions for BY4742, L40c, W303, and for Y258, respectively (Supplementary Table 2). The use of different lab strains further increased sensitivity. In total 25, 36, 49, and 89 kinases with severe growth reduction were detected in at least 4, 3, 2 or 1 yeast strain respectively.

The 266 human protein kinases were then clustered based on their activity (Figure 1C). For that, the kinases were grouped in four bins, according to number of conditions where they exhibit a growth phenotype and ranked separately for each strain. Hierarchical clustering revealed sets of kinases that were active in many conditions in one strain, two, or more strains, respectively. We grouped kinases according to their activity profiles across the four strains into three activity groups, from topmost active through highly to moderately active kinases (Figure 1C, Supplementary Table 2). In agreement with previous observations [5], the topmost active kinases included cytoplasmic tyrosine kinases, which caused strong growth reduction when overexpressed in yeast. They also included two PKC family members (alpha and epsilon), two p38 MAP kinase family members (alpha and beta) as well as the cell cycle kinases CDK2, CDK3. Likewise, MARK3, RIPK2, NEK6, CDK17, CSNK2A2, AURKA, DYRK4, DYRK1B, and PKA were members of the high activity group, with their expression frequently resulting in growth reduction (Figure 1C, box with the top 30).

Next, we compared the percentage of strong growth phenotypes caused by human kinases which have homologous kinase(s) in S. cerevisiae with human kinases that do not have homologs in yeast. Tyrosine kinases were treated as a separate group because tyrosine kinase signaling is a hallmark of multicellularity and did not evolve in yeast. Aberrant tyrosine phosphorylation can be toxic in yeast and it was suggested that organisms with evolved tyrosine signaling have a substantially reduced tyrosine content to prevent adverse tyrosine phosphorylation [41]. The results illustrate that the percentage of kinases causing a strong growth phenotype per condition is highest amongst the tyrosine kinases. The 
bioRxiv preprint doi: https://doi.org/10.1101/2021.11.18.469002; this version posted November 19, 2021. The copyright holder for this preprint (which was not certified by peer review) is the author/funder, who has granted bioRxiv a license to display the preprint in perpetuity. It is made available under aCC-BY-NC 4.0 International license.

Kinase array, 11/18/2021

percentage of serine/threonine kinases causing a strong growth phenotype per condition is higher for the human kinases with a homolog in yeast than for those without (Figure 1D). This on one hand confirms that high level tyrosine phosphorylation in yeast is harmful, and on the other hand showed a significant trend suggesting that conserved S/T-kinases are more likely to interfere with essential yeast cellular process perturbing yeast growth than heterologous expression of non-conserved kinases.

\section{Kinase activity is critical for yeast growth phenotypes}

Evaluation of the yeast growth phenotype under a variety of growth conditions allowed monitoring the effects of the expression of individual human kinases through a simple readout such as colony size on agar. However, heterologous expression of any protein in yeast as such can affect yeast growth, independently of the activity of the expressed protein. Therefore, we asked whether kinase phosphorylation activity and not human protein overexpression per se drives our phenotypic readout.

We first compared the number of growth phenotypes caused by the human protein kinases with the number of growth phenotypes observed with the control set of proteins without kinase activity. The statistical comparison of the number of observed phenotypes for the two groups reveals that kinase expression resulted in growth defects much more often than expression of unrelated proteins or phosphorylation-inactive kinase versions (Figure 2A).

To experimentally validate the impact of kinase activity on observed growth phenotypes in the yeast array, we monitored growth measuring the optical density of liquid cultures of wild type kinase in parallel with kinase-dead mutant version over 24 hours. The results for BUB1 and NEK6 illustrate that there is no difference in yeast growth under standard growth condition in this assay. The addition of $3.2 \%$ DMSO to the media inhibited yeast growth, observable through a shallower growth curve and lower maximum cell density. In the presence of DMSO, the expression of the wildtype kinase of BUB1 or NEK6 diminishes yeast growth in comparison to the respective BUB1 (K821M) and NEK6 (K74M\&K75M) kinase-dead mutants (Figure 2B). The comparison of yeast growth upon expressing either the activated form of PKC $\alpha$ (A25E) or the PKC $\alpha(\mathrm{K} 368 \mathrm{R})$ kinase-dead mutant revealed pronounced differences under both standard and 3.2\% DMSO growth conditions (Figure 2B). These results of this liquid growth assay were in good agreement with the results of the solid media screen, confirming that the kinase activity is required to inhibit yeast growth.

To directly show kinase activity in the yeast strains we assayed kinases for their ability to phosphorylate endogenous yeast proteins using phospho-specific antibodies. To this end, whole cell lysates from yeast expressing human kinases were subjected to SDS-PAGE and western blotting and probed with either a general phospho-tyrosine recognizing antibody (4G10) or five different phospho-substrate antibodies which recognize phosphorylated S/T-sites preferentially in a certain amino acids sequence context

(Figure 2C). Equal amount of whole cell lysate was probed comparing different kinases as well as kinases with the respective kinase-dead mutant variants. As illustrated for PKC $\alpha, \mathrm{p} 38 \alpha$, AURKB, and FYN in Figure 2C, diverse patterns of immunoreactivity were obtained when probed with indicated 
bioRxiv preprint doi: https://doi.org/10.1101/2021.11.18.469002; this version posted November 19, 2021. The copyright holder for this preprint (which was not certified by peer review) is the author/funder, who has granted bioRxiv a license to display the preprint in perpetuity. It is made available under aCC-BY-NC 4.0 International license.

Kinase array, 11/18/2021

antibodies. Most tyrosine kinases phosphorylated yeast proteins, albeit with different sensitivity and specificity [5]. Endogenous serine and threonine phosphorylation in yeast is high. Therefore, phosphorylation patterns were distinguishable from background signals for only a subset of the tested kinases and antibodies. In total, 27 human protein kinases showed phosphorylation activity towards yeast proteins with one of the six available antibodies (Figure 2C). These experiments showed that human kinases are active in yeast and phosphorylate yeast proteins.

\section{The kinase array is a versatile tool to study human kinase activities}

Our array set up to study kinase activities revealed a set of 150 highly active kinases (topmost and highly active). This subset of the human kinome included representatives from all major kinase families (Figure 3A). Many well characterized kinases are known cancer drivers, and more than 340 human kinases are associated with at least one type of cancer [42]. 95 of the highly active kinases overlap with this cancer kinase set (Figure 3B). One major strength of the yeast kinase array is that it also covers a large number of less well studied or difficult to study kinases. 162 kinases, nearly one third of the kinome, have been designated by the NIH as being poorly understood. As their role or biological function is largely unknown they are termed 'dark kinases' [10]. Our array contained 72 dark kinases, 35 of which were in the group of highly active kinases (Figure $3 \mathbf{C}$ ).

In general, studying kinases in their cellular environment is challenging, as kinase perturbation results in widespread pleiotropic cellular effects. In addition, many kinases are also highly tissue specific and/or low abundant, posing further challenges for the characterization of activities. We used protein abundance data from 31 tissues from the PAXdb (Protein Abundance Database), that provides normalized relative protein abundance data across many diverse mass spectrometry-based proteome studies [43]. The kinome tree view shows that tissue specific and low-abundance kinases are well covered in our array (Figure 3D, tissue expression, Figure 3E, average protein abundance). For example, two members each of the TSSK, MARK or DRYK kinases, all highly active in yeast, belong to the dark, tissue-specific group of kinases with low expression. The activity of human kinases in the yeast array is largely independent of endogenous expression levels in human cells, thus enabling to study all candidate kinases equally well.

\section{Phospho-yeast two-hybrid for identification kinases modulating PPIs}

In our system, the activities of many human kinases can be monitored by growth reduction under varying conditions. However, low to moderate expression of human kinases under standard conditions does not impair yeast growth. Therefore, this kinase expression array opens avenues to alternative screening approaches, where the activity of a kinase can be assessed when coupled to any functional assay or readout in yeast. Cellular assays can involve drug inhibition/resistance selection, expression of a reporter such as luciferase, or expression of a fluorescent or epitope-tagged protein, or functional genomics readouts such sequencing or mass spectrometry [44]. To explore the screening possibilities offered by 
bioRxiv preprint doi: https://doi.org/10.1101/2021.11.18.469002; this version posted November 19, 2021. The copyright holder for this preprint (which was not certified by peer review) is the author/funder, who has granted bioRxiv a license to display the preprint in perpetuity. It is made available under aCC-BY-NC 4.0 International license.

Kinase array, $11 / 18 / 2021$

the kinase array, we applied a phospho-yeast two-hybrid system [19] to identify kinases that modulate phosphorylation-dependent protein-protein interactions. The phosphorylation of one protein can either abolish its ability to interact with its partner, resulting in a loss of interaction, or it can enable the interaction with a second protein leading to a gain of interaction (Figure 4A). Both types of phosphorylation-dependent PPI switches require an active kinase facilitating the phosphorylation of one of the interaction partners. In the first setup where phosphorylation abolishes the $\mathrm{Y} 2 \mathrm{H}$ interaction, active kinases are expressed from a third plasmid and phosphorylate either the bait or prey protein, resulting in reduced yeast growth on selective media. Conversely, the kinase activity can also promote yeast growth on selective media when the kinase activity enables a protein complex formation (Figure 4A). Modulation of protein interactions by phosphorylation has been widely described in the literature [45], however it often remains unclear which kinase(s) are responsible for interaction regulation. There are many "kinase-orphan" phosphorylation-dependent interactions described in the literature [46] but no systematic approach tailored towards identifying kinases directly involved in phospho-mediated modulation of protein interactions has been reported. Our kinase array allows us to identify such kinases with a phospho-Y2H matrix approach (Figure 4B). A bait-prey pair of human proteins is co-expressed in one yeast strain (L40c mata) and mated with each of the L40c mat $\boldsymbol{a}$ strains in the kinase array. The active kinases modulating the interaction of the two proteins of interest are then identified by altered yeast growth patterns (Figure 4A). To test the utility of this array in identifying biologically relevant kinase activities, we screened two well characterized phosphorylation-dependent interactions, which represent the two cases and for which the responsible modulatory kinases are as yet unknown.

\section{Kinase-dependent inhibition of the spliceosomal AAR2 - PRPF8 interaction}

PRP8 is a major constituent of the spliceosome, delivered as part of the U5 snRNP complex during the spliceosomal assembly cycle. AAR2 is a U5 snRNP and U4/U6-U5 tri-snRNP assembly factor. In yeast, AAR2 is thought to dissociate from PRP8 at late assembly stages based on a phosphorylation trigger freeing PRP8 to allow for BRR2 binding (Figure 5A). While these events, including the crucial AAR2 phosphorylation site at serine 253 , are well characterized in yeast [47-49], the kinase(s) responsible for the phosphorylation are unknown.

Here we investigate the phospho-dependent AAR2-PRPF8 interaction with the human proteins. The two proteins are conserved between yeast and human, however, it is not immediately evident from a standard sequence alignment whether the AAR2 phosphorylation sites including yeast serine 253 are conserved. The human AAR2-PRPF8 complex has been crystalized for high resolution structure determination [50]. We superimposed the two structures of the yeast and human Aar2/AAR2 protein and hypothesized that serine 284 in human may be functionally equivalent to serine 253 in yeast (Figure 5B). Notably, phosphorylation of the mammalian serine 284 is reported in PhosphoSitePlus [51]. Next, we recapitulated the interaction-disrupting effect of S253 phosphorylation observed in S. cerevisiae with the human orthologs using a Y2H approach (Figure 5C). Human PRPF8 bait (aa1755-2335) interacts 
bioRxiv preprint doi: https://doi.org/10.1101/2021.11.18.469002; this version posted November 19, 2021. The copyright holder for this preprint (which was not certified by peer review) is the author/funder, who has granted bioRxiv a license to display the preprint in perpetuity. It is made available under aCC-BY-NC 4.0 International license.

Kinase array, 11/18/2021

with full length human AAR2 prey using our standard Y2H system [38,52]. While the S284A AAR2 mutant version has no effect, the S284E phospho-mimetic mutant in AAR2 abolished the Y2H growth readout (Figure 5C). In a control experiment, we assayed a second candidate phospho-site, T356A and T356E AAR2 mutant versions [47], also in combination with S284E, which confirmed that the S284 phospho-mimetic version of AAR2 was sufficient to abolish binding of PRPF8 in the human system (Figure 5C). When immunoprecipitating the human PRPF8 RNase H-like domain fragment from transfected HEK293 cells, both the wildtype AAR2 and the non-phosphorylatable S284A mutant versions showed comparable binding, while the S284E phospho-mimetic mutant completely abolished the interaction (Figure 5D).

In order to identify candidate human kinases that can mediate this phosphorylation-dependent PPI switch, we screened each of the 266 kinases for loss of the Y2H signal (Figure 5E). We transformed L40c mat $\alpha$ with the PRPF8-AAR2 bait and prey plasmids and mated this strain against the validated L40c mata kinase array. Each diploid strain expressed the two interacting proteins as well as one human kinase. After transfer on selective media we identified two candidate kinases SGK2 and CK2 $\alpha 1$ (CSNK2A1), that reproducibly had a negative effect on $\mathrm{Y} 2 \mathrm{H}$ reporter-dependent yeast growth (Figure 5E). Because $\mathrm{Y} 2 \mathrm{H}$ utilizes a transcriptional reporter system, which has high sensitivity also to transient and less stable interactions [53], we do not expect that this setup will lead to complete loss of the signal. Rather, reduced, sub-stoichiometric phosphorylation of AAR2 may well account for the observed decrease in yeast growth of the SGK2 and CK2 21 strains.

To validate the kinase array phospho-Y2H results, AAR2 and PRPF8 were tested in a co-expression and immunoprecipitation assay in HEK293 cells. Co-expression of either SGK2 or CK2 $\alpha 1$ reduced the amount of wild-type AAR2 co-immunoprecipitated with PRPF8 in comparison to the non-phosphorylatable mutant S284A (Figure 5F). Together, these experiments in mammalian cells support the results obtained with the kinase array when coupled to the phospho- $\mathrm{Y} 2 \mathrm{H}$ assay. Active SKG2 and CK2 $\alpha 1$ kinases substantially reduced the spliceosomal assembly complex interaction of AAR2 and PRPF8, and may thus be involved in triggering the interaction switch of PRPF8 from AAR2 to BRR2 in mammalian cells.

\section{Kinase-dependent interaction of ER $\alpha$ and 14-3-3 proteins}

We next sought to test the utility of the kinase array in identification of kinases that promote protein-protein interactions. Estrogen receptor alpha (ER $\alpha)$, the hormone ( $\beta$-estradiol) sensing nuclear receptor frequently overexpressed in breast cancer, is heavily post-translationally modified, including 26 phosphorylated residues [51]. Interestingly, De Vries-van Leeuwen et al. reported that ER $\alpha$ dimerization is inhibited through a phosphorylation-dependent interaction of the ER $\alpha$ monomer with 14-3-3 proteins. Mediated by the ER $\alpha$ C-terminal phospho-threonine 594, the interaction prevents the activation of ER $\alpha$-dependent transcription (Figure 6A), yet kinases which direct this inhibitory action remain elusive [54]. 
bioRxiv preprint doi: https://doi.org/10.1101/2021.11.18.469002; this version posted November 19, 2021. The copyright holder for this preprint (which was not certified by peer review) is the author/funder, who has granted bioRxiv a license to display the preprint in perpetuity. It is made available under aCC-BY-NC 4.0 International license.

Kinase array, 11/18/2021

For phospho-Y2H analysis, we co-transformed L40c mat $\alpha$ with ER $\alpha$ bait and 14-3-3 prey constructs for interaction mating with the human kinase yeast array. While ER $\alpha$ did not show interaction with 14-3-3 $\beta$ across multiple replicas in a classical $\mathrm{Y} 2 \mathrm{H}$ experiment in the absence of a kinase (Figure 6B, Ctrl), the kinases BUB1, NEK6, CDK17, and PAK5 were able to reproducibly promote the interaction as indicated by the yeast growth on selective agar (Figure 6B). Parallel screening of NEK6(K74M\&K75M), PAK5(K478M), BUB1(K821M), and CDK17(K221M) kinase-dead mutants suggested that phosphotransferase activity is required to promote the ER $\alpha-14-3-3 \beta$ interaction for the kinases NEK6 and BUB1. In contrast, kinase-dead mutants of PAK5 and CDK17 still promoted growth on $\mathrm{Y} 2 \mathrm{H}$ selective medium (Figure 6B).

Up to $40 \%$ of the human kinome was predicted to bind to 14-3-3 proteins (including CDK17), and about 30 human protein kinases, including PAK5, have been shown to directly bind 14-3-3 proteins [55]. As PAK5 and CDK17 can potentially bind both ER $\alpha$ and 14-3-3, they may form a relatively stable ternary complex and therefore drive the positive $\mathrm{Y} 2 \mathrm{H}$ signal in a phosphorylation-independent manner. To test this hypothesis, we performed a co-immunoprecipitation assay with a luciferase-based readout with 14-3-3 $\beta$ and wildtype as well as kinase-dead mutants of BUB1, NEK6, PAK5 and CDK17. The results indicated that the kinases PAK5 and CDK17 were able to bind to 14-3-3 $\beta$ while there no was binding detected for the wildtype or kinase-dead mutants of BUB1 or NEK6 (Supplementary Figure 1 to 6B). Together with the phospho-Y2H results using kinase-dead mutants, these results are consistent with a model whereby PAK5 and CDK17 drive the Y2H interaction through formation of more stable ternary complexes with ER $\alpha$ and 14-3-3, while BUB1 and NEK6 promote ER $\alpha$ - 14-3-3 interaction mainly through phosphorylation.

To analyze whether the co-expression of the kinases BUB1, NEK6, PAK5 and CDK17 in HEK293 cells results in an increased phosphorylation of $E R \alpha$, the phosphorylation status of ER $\alpha$ was determined with an in-gel phospho-stain. While no kinase activity of CDK17 and BUB1 could be detected on ER $\alpha$ after immunoprecipitation, the kinases NEK6 and PAK5 promoted the phosphorylation of ER $\alpha$, in comparison to the corresponding kinase-dead mutants or the control sample without kinase overexpression (Figure 6C). A pulldown assay with bacterial-expressed GST-tagged 14-3-3 $\beta$ resulted in ER $\alpha$ binding if co-expressed with the wildtype kinases NEK6 or PAK5 in HEK293 cells when compared to the kinase-dead mutant co-expression or negative control experiments (Figure 6D). This result is consistent with the observed ER $\alpha$-phosphorylation activity of NEK6 and PAK5 in HEK293 cells.

To summarize, NEK6 and BUB1 promote the association of 14-3-3 $\beta$ and ER $\alpha$ in Y2H in a kinase activity-dependent manner, and do not directly interact with 14-3-3 $\beta$ themselves. When co-expressed in mammalian cells, active forms of NEK6 and PAK5 increase the phosphorylation of ER $\alpha$ and its direct binding to $14-3-3 \beta$ in GST pulldown assays. Together, these protein interaction data point to NEK6 as a prime candidate to regulate the association of ER $\alpha$ with $14-3-3 \beta$ and thereby its transcriptional activity 
bioRxiv preprint doi: https://doi.org/10.1101/2021.11.18.469002; this version posted November 19, 2021. The copyright holder for this preprint (which was not certified by peer review) is the author/funder, who has granted bioRxiv a license to display the preprint in perpetuity. It is made available under aCC-BY-NC 4.0 International license.

in vivo. To test this hypothesis, we transfected HEK293T cells with ER $\alpha$ and ER $\alpha$-dependent luciferase reporter harboring three copies of Estrogen Response Element in front of a minimal promoter and a luciferase gene (3xERE-LUC, [56]), in presence of increasing amounts of wild-type or kinase-dead NEK6. The co-transfection of active NEK6 kinase inhibited estrogen-driven activation of the luciferase reporter in a dose-dependent manner (Figure 6E). The observed effect was dependent on the kinase activity of NEK6, as the attenuation of ER $\alpha$ transcriptional activity was negligible with the kinase-dead NEK6-KD version. This effect was reproduced in MCF7 cells, a breast cancer cell line and a standard model to study ER $\alpha$ transcriptional activity. Finally, also in U2-OS cells, the osteosarcoma cell line originally used by De Vries-van Leeuwen et al. to demonstrate the effects of 14-3-3 binding, active NEK6 kinase also reduced the ER $\alpha$-dependent reporter gene transcription (Figure 6E). These results, obtained in three relevant mammalian cell lines, functionally support the results of our human kinase array screening approach, suggesting that NEK6 is a prime candidate kinase that can promote phosphorylation of $\mathrm{ER} \alpha$ and its interaction with 14-3-3 proteins.

\section{Discussion}

Kinase activity drives signaling processes and, when deregulated, human diseases. Kinases are the third largest group of human protein drug targets and kinase inhibitors represent the largest fraction of drugs with poly-pharmacological effects, that is they act through multiple targets [8]. However, beyond their primary sequence and domain architecture, a large fraction of human kinases are hardly characterized $[9,10]$. Systematic assaying multiple kinases activities in parallel is therefore fundamental to improve our understanding of cellular signaling, disease processes and drug action [9,57].

Experimental methods for assaying kinase activities include in vitro assays with recombinant proteins [57,58] or the application of kinase specific biosensors that work in cells [12-14]. For example, an enzyme assay panel employing more than 200 recombinant kinases was used with microfluidics capillary electrophoresis technology to screen for small molecule inhibitors [57]. Because results using recombinant kinases in vitro do not always recapitulate in vivo conditions, other approaches prove valuable to assay kinase activities. Taipale et al. [59] used the interaction of HSP90 / CDC37 chaperones with kinases as thermodynamic sensors of kinase activity or inhibitor binding in a cell culture co-IP approach. Also fluorescent biosensors examining conformational changes of kinase allow to temporally and spatially resolve kinase activities towards engineered targets in cells, tissues, and to some extent in whole organism $[11,13,14]$. Clearly, accessible tools to study active kinases under cellular conditions are a useful addition to current approaches.

This study presents information about the activity of 266 human protein kinases obtained from a yeast array, using growth as a readout [44]. While most kinases when expressed at low levels in yeast do not bestow a growth phenotype, we have increased sensitivity of the growth readout by employing a variation of growth conditions and by using four distinct yeast strains. Comparison to a set of non-active 
bioRxiv preprint doi: https://doi.org/10.1101/2021.11.18.469002; this version posted November 19, 2021. The copyright holder for this preprint (which was not certified by peer review) is the author/funder, who has granted bioRxiv a license to display the preprint in perpetuity. It is made available under aCC-BY-NC 4.0 International license.

Kinase array, 11/18/2021

kinases and unrelated proteins indicated that although some phenotypes might be related to protein overexpression, this effect was not dominant. Moreover, some kinases may not be active in yeast because of the lack of regulatory proteins, or conversely, we may miss the activity of a set of kinases, where phosphorylation of yeast proteins simply is not detrimental to growth. For example, even though SGK2 and PAK5 were both grouped with the moderately active kinases, they could be identified from the array as candidates for modulating pS/T-PPIs because of the use of an alternative phospho-Y2H readout.

Examination of the yeast array yielded 150 highly active kinases. Our active kinase set is representative of the kinase families (Figure 3) and covers 35 members of the dark kinome [10], including CDK17, NEK6 and MARK3. The human kinase array can be leveraged for a variety of assays, provided the activity of a kinase can be coupled to a growth selection or other readouts. As proof of principle, we used the array to identify kinases that can modulate known $\mathrm{pS} / \mathrm{T}$-dependent protein interactions in a phospho-Y2H screen. While several approaches exist to define phospho-mediated PPIs, the kinases that modulate the PPI often remain elusive and so far, no systematic approach to identify them is available. First, we addressed the interaction of the spliceosomal protein PRPF8 and the snRNP assembly factor AAR2. Here we showed that phosphorylation of S284 of human AAR2 disrupts the interaction with PRPF8 (Figure 5), which in analogy to yeast is thought to constitute an important step in U5 snRNP and U4/U6-U5 tri-snRNP biogenesis $[47,48]$. The spliceosome is the large macromolecular proteinRNA complex that catalyzes pre-mRNA splicing. It assembles and disassembles on each pre-mRNA in a highly coordinated, stepwise manner governed by multi-protein-RNA interactions [52,60]. In yeast, cytoplasmic assembly of the U5 snRNP includes the assembly factor Arr2 in place of the spliceosomal helicase Brr2, which requires tight regulation [61]. There the binding of Arr2 to Prp8 blocks the Prp8 binding site of Brr2. As the Brr2-Prp8 interaction is blocked, Brr2 helicase activity may be shut off during this phase of U5 snRNP assembly. Nuclear phosphorylation of Aar2 disrupts its interaction with Prp8 and allows incorporation of Brr2 into U5 snRNP, and subsequently the U4/U6-U5 tri-snRNP through which Brr2's helicase function is eventually delivered to the spliceosomal pre-catalytic B complex [48,49]. Subject to further scrutiny, a similar phosphorylation-dependent regulation of the AAR2-PRPF8 interaction is also thought to play a role in U5 snRNP or U4/U6-U5 tri-snRNP assembly in human. The kinase that could contribute in this regulation is presently unknown.

Screening the L40c yeast kinase array for a loss of the Y2H AAR2-PRPF8 bait-prey interaction revealed that the kinases SGK2 and CK2 $\alpha 1$ are able to reduce the interaction (Figure 5). This result was confirmed by co-immunoprecipitation assays in HEK293 cells, where co-expression of wild type SGK2 or CK2 $\alpha 1$ reduced the amount of AAR2 co-precipitated with PRP8. The AGC kinase group member SGK2 is not characterized very well. SGK kinases, just like AKT/PKB kinases are activated by PDK1 through phosphorylation of conserved residues [62]. SGK2 is known to be involved in the phosphorylation of diverse set of cellular channels and receptors [63] including V-ATPase proton pump [64]. The other candidate CK $2 \alpha 1$, however, is a constitutively active kinase primarily located in the 
bioRxiv preprint doi: https://doi.org/10.1101/2021.11.18.469002; this version posted November 19, 2021. The copyright holder for this preprint (which was not certified by peer review) is the author/funder, who has granted bioRxiv a license to display the preprint in perpetuity. It is made available under aCC-BY-NC 4.0 International license.

nucleus and thus could support disruption of the AAR2-PRPF8 interaction in the nucleus during late stages of U5 or U4/U6-U5 assembly. CK2 $\alpha 1$ has been reported to phosphorylate a vast number of substrates and to regulate numerous cellular processes [65-67], including cell cycle progression, apoptosis and transcription, as well as a viral infection. It is involved in other spliceosomal processes such as the phosphorylation of Prp3 [68,69], the exon junction complex member / splicing activator RNPS1 [70] and is associated with the U4/U6/U5 tri-snRNP complex [67].

Estrogen receptor alpha (ER $\alpha$ / ERS1) is one of the most highly studied hormone sensing nuclear receptors. Its dimerization is essential for its ligand-dependent transcriptional activity. Blocking ER $\alpha$ function is the major route to treat luminal (ER+) breast cancer. $\mathrm{ER} \alpha$ is phosphorylated at various sites, and potential functions and protein kinases for some phosphorylation sites have been characterized [71]. A phosphorylation-dependent interaction between ER $\alpha$ and the phospho-binding adaptors 14-3-3, which reduces the transcriptional activity and the proliferative effect of ER $\alpha$ in cells has been reported. The authors specifically demonstrated that phosphorylation of ER $\alpha$ is required for the binding of 14-3-3 protein and proposed that stabilization of this interaction with its effect on ER $\alpha$ transcriptional activity may be of therapeutic value [54].

We identified four candidate kinases, BUB1, NEK6, PAK5 and CDK17, with the ability to promote the interaction of ER $\alpha$ with $14-3-3 \beta$ in a phospho-Y2H matrix approach from screening the kinase L40c array (Figure 6). In this assay, kinase activity of BUB1 and NEK6 was required to promote the interaction, whereas kinase inactive versions of PAK5 and CDK17 were also sufficient for a positive $\mathrm{Y} 2 \mathrm{H}$ growth readout. The latter results are explained by the ability of the two kinases to stably bind to 14-3-3 proteins. This binding is reported in the literature [55] and was confirmed in luciferase-based coimmunoprecipitation experiments. However, we detected increased phosphorylation of ER $\alpha$ phosphorylation in HEK293 cells upon co-expression of wild type NEK6 and PAK5 kinase. Expression

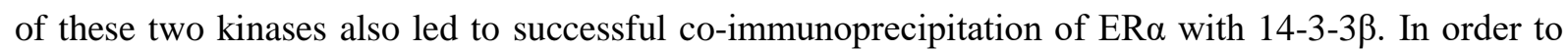
demonstrate that NEK6 phosphorylation-dependent increase of ER $\alpha-14-3-3$ interaction can have functional consequences in cells, we performed ER $\alpha$-dependent transcription activation assays. In all three cell lines tested, HEK293, the breast cancer cell line model MCF-7 and U2-OS cells, overexpression of the active NEK6 kinase reduced transcriptional activity in a dose-dependent manner, an effect not observed with the kinase inactive NEK6 variant.

Among the four candidate kinases with the potential to modulate ER $\alpha$ activity via a phosphorylation-dependent interaction with 14-3-3 proteins we have identified, BUB1 is a fairly well characterized kinase involved in spindle checkpoint control [72]. In contrast, PAK5, CDK17 and NEK6 belong to the group of understudied, less well characterized kinases. PAK5 (formerly PAK7) is an actin and microtubule associated p2 $1^{\text {cdc42/rac1 }}$-activated kinase family member [73], which has been shown to promote proliferation, invasion and migration of various cancer cell models [74]. CDK17 (also PCTAIRE2) is an uncharacterized member of the cyclin-dependent kinase family [75]. Taken together, 
our data point to NEK6, a cell cycle kinase involved in progression through mitosis [76,77], with only few substrates known so far [78], as the strongest candidate as ER $\alpha$ effector.

\section{Conclusion}

Here, we built on the observation that heterologous expression of human kinases in yeast can cause a growth defect attributed to the enzymatic phosphotransferase activity of these proteins $[29,30,44]$. We have demonstrated that a large fraction of human kinases (56\%) is active in our yeast array. For a subset of kinases, we have also demonstrated the kinase activity directly using kinase-dead mutant version as comparisons, or through monitoring the extent of yeast protein phosphorylation with phospho-specific antibodies. Mechanism that explain why aberrant phosphorylation of yeast proteins impar yeast growth are largely elusive and may be different from kinase to kinase. Whether or not kinase activity can be reported using the yeast array depends on growth conditions, the yeast strain and the readout used. Readouts where kinase activity is coupled to growth inhibitory effects, either directly or via a reporter system, can be used to study kinase perturbation [23] and inhibition [18,30,79,80]. Under conditions of low kinase expression levels, that do not impair growth, different setups can be utilized to pick up kinase activities, for example mass spectrometry-based substrate identification [5] or screens for pY-dependent protein interactions [19]. Here, we extended the phospho-Y2H approach to S/T kinases for the first time, utilizing the array to identify kinases that can modulate known $\mathrm{pS} / \mathrm{T}$-dependent protein interactions. Knowledge of potential kinases that regulate phospho-dependent protein interactions, many of which are prime drug targets, can lead to novel pharmacological intervention strategies. Therefore, the human kinase array approach is a versatile methodological addition, allowing to perform comprehensive studies of human kinases and their effects. 


\section{Material and Methods}

\section{Antibodies}

The following antibodies were used: $\mathrm{mAB}$ anti-phospho-CDK substrate (pTPXK, rabbit, Cell Signalling, 14371), mAB anti-phospho-CK2 substrate MultiMab ${ }^{\mathrm{TM}}$ ((pS/pT)DXE, rabbit, Cell Signalling, 8738), mAB anti-phospho- MAPK/CDK substrate (PXS*P or SPXR/K, rabbit, Cell Signalling, 2325), mAB anti-phospho-PKA substrate (RRXS*/T*, rabbit, Cell Signalling, 9624), pAB anti-phospho-(Ser)-PKC substrate $\left((\mathrm{R} / \mathrm{K}) \mathrm{X}\left(\mathrm{S}^{*}\right)(\mathrm{Hyd})(\mathrm{R} / \mathrm{K})\right.$, rabbit, Cell Signalling, 2261), pAB antiGST (goat, GEHealthcare, 27457701V), mAB anti-HA (mouse, Hiss Diagnostics GmbH, AB-10110), $\mathrm{mAB}$ anti-phospho-tyrosine clone 4G10 (mouse, Millipore, 05-321), secondary mAB anti-goat HRP (rabbit, Invitrogen, 611620), secondary mAB anti-mouse (sheep, GE Healthcare, LNA931V), secondary mAB anti-rabbit (donkey, GE Healthcare, LNA934V);

\section{Yeast strains}

BY4742 (MAT $\alpha$ ) MAT $\alpha$ his3 $\Delta 1$ leu2 $\Delta 0$ lys2 $\Delta 0$ ura3 $\Delta 0$, [35,36]; L40c (MATa) his3 $\Delta 200$ trp1-901

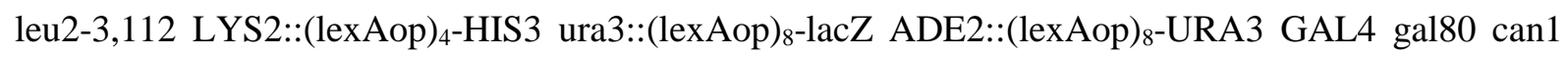
cyh2 [37,38]; W303 (MATa/MAT $\alpha$ ) leu2-3,112 trp1-1 can1-100 ura3-1 ade2-1 his3-11,15 [39]; Y258 (MATa) pep4-3 his4-580 ura3-52 leu2-3 [40];

\section{Growth phenotype screen}

Supplementary Table 1 lists all conditions successfully tested including concentrations of additives. The four yeast strains were transformed with 1,020 clones (pASZ-C-DM or pASZ-CN-DM) representing kinases and protein set. For the growth phenotype screen, the kinase yeast array was transferred in 384 format using a gridding robot and grown on agar plates with minimal medium with $2 \%$ glucose and 20 $\mu \mathrm{M} \mathrm{CuSO}_{4}$ at $30^{\circ} \mathrm{C}$ unless otherwise stated (6-8 days). Yeast growth strength was visually evaluated in comparison to the overall growth of the yeast strain in the one condition and recorded using a 0-3 scale. For each of the four strains, plotting the number of conditions over the number of kinases with growth phenotype gave a bimodal distribution separating conditions with relatively fewer specific kinase signals from conditions that have a general diminishing effect on yeast growth. According to this distribution, conditions which reduced growth of more than 175 colonies were excluded from further analysis.

\section{Phospho-Y2H Screen}

The general Y2H set-up has been described in detail previously [38]. For the phospho-Y2H screen, the L40c $\alpha$ Y2H strain was co-transformed with the plasmids expressing the bait constructs (pBTM116-D9 or pBTMcC24-DM) and the prey constructs (pCBDU-JW or pACT4-DM). The independently 
transformed yeast colonies were mated with the L40c kinase array strains on YPD agar $\left(30^{\circ} \mathrm{C}, 2\right.$ days). Active kinases modulating the phosphorylation-dependent PPI were identified by growth on selective media (SD5) supplemented with $20 \mu \mathrm{M}$ or $100 \mu \mathrm{M} \mathrm{CuSO}_{4}$ for the induction of kinase expression $\left(30^{\circ} \mathrm{C}\right.$, 3-5 days).

\section{Yeast growth curves}

To measure yeast growth in liquid culture, triplicates of the W303 strain expressing a single human protein kinase were created on agar, transferred to liquid media in microtiter plate format. For the growth measurement, a 96-well MTP was incubated for $1 \mathrm{~h}$ at $30^{\circ} \mathrm{C}$ with orbital shaking, the yeast was then diluted with selective media ( $\mathrm{SD} 5,500 \mu \mathrm{M} \mathrm{CuSO}_{4}$ ) with or without $3.2 \%$ (v/v) DMSO to a starting $\mathrm{OD}_{595}$ of $0.10-0.15$. Then yeast growth was recorded in the MTP for $24 \mathrm{~h}$ by taking the OD every 10 min and shaking every hour for $5 \mathrm{~min}$.

\section{Protein interaction assays in mammalian cells}

HEK293T cells were cultured in Dulbecco's modified eagle medium (DMEM) with 10\% fetal bovine serum (FBS) in a humidified 5\% CO 2 atmosphere at $37^{\circ} \mathrm{C}$. For the immunoprecipitation and pull-down experiments $\sim 6 \times 10^{7} \mathrm{HEK} 293 \mathrm{~T}$ were cells plated in a $10 \mathrm{~cm}$ cell culture dish and incubated for 24 prior to transfection. A total of $4 \mu \mathrm{g}$ DNA of the different constructs were used for transfection with Lipofectamine 2000.

\section{GST pull-down experiments form HEK293T cells (AAR2-PRPF8 interaction)}

GST-tagged AAR2 (pcDNA5/FRT/TO-nGST) and the HA-Strep-tagged PRPF8 (pcDNA5/FRT/TO/SH/GW) constructs were co-transfected with PA-tagged kinase in HEK293T cells. HA-Strep-tagged PRPF8 protein was pulled down with Strep-Tactin Sepharose and the amount of bound AAR2 protein was determined by western blotting. Cells were harvested $24 \mathrm{~h}$ after protein expression induction lysed in $0.5 \mathrm{ml}$ LyseH-buffer (50 mM HEPES, $500 \mathrm{mM} \mathrm{NaCl}, 10 \%$ Glycerol, $0.5 \mathrm{mM}$ EDTA, $2 \mathrm{mM} \mathrm{MgCl} 2,1 \%$ NP-40, $12.1 \mathrm{mM}$ sodium deoxycholate, 1x Phosphatase inhibitor III, 1x Protease inhibitor, $0.1 \mathrm{U} / \mu 1$ Benzonase), cleared and incubated with human Strep-Tactin sepharose beads for $1 \mathrm{~h}$ on ice. The beads were washed four times with ice-cold WashH buffer (50 mM HEPES, $500 \mathrm{mM} \mathrm{NaCl}$, $10 \%$ Glycerol, $0.5 \mathrm{mM}$ EDTA, $2 \mathrm{mM} \mathrm{MgCl} 2,1 \% \mathrm{NP}-40,12.1 \mathrm{mM}$ sodium deoxycholate) and treated two times with $30 \mu 12 x$ SDS loading buffer for SDS-PAGE western blot analyses.

\section{Immunoprecipitation of ERa}

To analyze ER $\alpha$ phosphorylation in mammalian cells, PA-tagged ER $\alpha$ (pcDNA3.1PA-D57) was coexpressed with a GST-tagged kinase (pcDNA5/FRT/TO-nGST) in HEK293T cells, immunoprecipitated 
bioRxiv preprint doi: https://doi.org/10.1101/2021.11.18.469002; this version posted November 19, 2021. The copyright holder for this preprint (which was not certified by peer review) is the author/funder, who has granted bioRxiv a license to display the preprint in perpetuity. It is made available under aCC-BY-NC 4.0 International license.

and the phosphorylation status of ER $\alpha$ was analyzed with Pro-Q phospho-stain (Thermo Scientific) of SDS-PAGE. Transfected HEK293T cells were harvested $24 \mathrm{~h}$ after protein expression induction and lysed in $0.5 \mathrm{ml}$ LyseH-buffer for $30 \mathrm{~min}$ on ice. The cleared cell lysate was transferred onto pre-washed $30 \mu \mathrm{l}$ human IgG agarose beads and incubated $1 \mathrm{~h}$ on ice. The beads were washed four times with icecold WashH buffer and proteins were eluted with $30 \mu \mathrm{l} 2 \mathrm{x}$ SDS loading buffer. After SDS gel electrophoresis, the gels were stained with Pro-Q Diamond phospho-stain and subsequent SYPRO Ruby whole protein stain and scanned with a fluorescence scanner according to the manufacture's instructions.

\section{GST pull-down experiments form HEK293T cells (ERa-14-3-3 interaction)}

GST-tagged 14-3-3 constructs (pDESTcoG) were expressed in E. coli, then loaded on GST-coated beads and incubated with HEK293T cell lysate containing co-expressed PA-tagged ER $\alpha$ and GST-tagged kinases. The amount coprecipitated ER $\alpha$ was detected by western blotting. GST-tagged 14-3-3 was expressed in $12 \mathrm{ml}$ E. coli culture (TB-medium, $100 \mu \mathrm{g} / \mathrm{ml}$ ampicillin, $30 \mu \mathrm{g} / \mathrm{ml}$ chloramphenicol) for about $20 \mathrm{~h}$ at $37^{\circ} \mathrm{C}$ and $150 \mathrm{rpm}$ shaking. E. coli cells were lysed in $1.85 \mathrm{ml}$ LyseB buffer $(50 \mathrm{mM}$ HEPES, $5400 \mathrm{mM} \mathrm{NaCl}$, 5\% Glycerol, $1 \mathrm{mM}$ EDTA, 0.5\% Brij58, 1mg/ml Lysozyme, 2mM DTT). $0.1 \mathrm{U} / \mu 1$ Benzonase was added in $50 \mathrm{mM}$ HEPES $\mathrm{pH} 8,2 \mathrm{mM} \mathrm{MgCl}_{2}$ and incubated for $30 \mathrm{~min}$ at $4{ }^{\circ} \mathrm{C}$. $9 \mu \mathrm{l}$ supernatant with expressed 14-3-3 $\beta$ were used for the pulldown experiment with $5 \mu$ l human

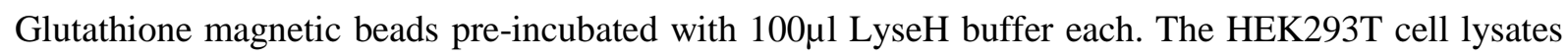
were prepared $24 \mathrm{~h}$ after protein expression induction in $0.5 \mathrm{ml}$ LyseH-buffer mixed with the GSTfusion beads with the bound 14-3-3 proteins and incubated on ice for $1 \mathrm{~h}$. The beads were washed six times with $0.5 \mathrm{ml}$ ice-cold WashH buffer and samples were eluted from the beads with $30 \mu 1$ 2x SDS loading buffer. Samples were subject to SDS gel electrophoresis and subsequent western blotting.

\section{Co-Immunoprecipitation with luciferase readout}

Luciferase based co-immunoprecipitation experiments were performed in HEK293T cells in 96 well format using $150 \mathrm{ng}$ of plasmid DNA in total (firefly-V5 fusion 14-3-3 $\beta$ construct in pcDNA3.1V5FireDM and kinase protein A fusion constructs in pcDNA3.1PA-D57) as described previously [52,81].

\section{Transient transfection luciferase transcription assays}

The cells were seeded out in phenol red - free DMEM supplemented with 10\% charcoal stripped FBS on 96-well plates. 24 hours after seeding the cells were transfected with indicated plasmids using PEI methods with PEI to DNA ratio of 5:1 w/w or 2.5:1 for HEK293T and MCF7 or U2-OS, respectively. Six hours after transfection, the cells were stimulated with $1 \mathrm{nM}$ E2 (17ß-estradiol). 24h after transfection, the cells were washed and lysed in Luciferase Cell Culture Lysis Reagent (Promega). The 
bioRxiv preprint doi: https://doi.org/10.1101/2021.11.18.469002; this version posted November 19,2021 . The copyright holder for this preprint (which was not certified by peer review) is the author/funder, who has granted bioRxiv a license to display the preprint in perpetuity. It is made available under aCC-BY-NC 4.0 International license.

Kinase array, 11/18/2021

luciferase activity was quantified using Luciferase Assay System (Promega) and normalize to the protein content.

\section{Data processing and visualization}

Data processing, statistical analyses and visualization was performed in R, kinome tree graphics were produced using CORAL at http://phanstiel-lab.med.unc.edu/CORAL/. 


\section{Author Contributions}

Conceptualization: US

Formal Analysis: SJ, NK; JW, US

Funding acquisition: US, MW

Investigation: SJ, NK, NB, GW

Methodology: SJ, JW, US

Resources: US, MW

Supervision: US, MW

Validation: SJ, NB, NK

Visualization: NK, SJ, JW, US, GW

Writing - original draft: US

Writing - review \& editing: NK and all authors

\section{Acknowledgments}

The work was supported by the Max Planck Society and the University of Graz.

\section{Conflict of interest statement}

The authors declare that there is no conflict of interest. 
bioRxiv preprint doi: https://doi.org/10.1101/2021.11.18.469002; this version posted November 19, 2021. The copyright holder for this preprint (which was not certified by peer review) is the author/funder, who has granted bioRxiv a license to display the preprint in perpetuity. It is made available under aCC-BY-NC 4.0 International license.

Kinase array, $11 / 18 / 2021$

\section{Figure legends}

\section{Figure 1: The human kinase yeast array.}

A. Schematic representation of the principle of the kinase yeast array and a flow diagram showing the construction of the human kinase array.

B. The Human Kinome Tree representing 518 kinases in nine families (modified from [2] using CORAL at http://phanstiel-lab.med.unc.edu/CORAL/). Pie charts indicate the fraction of kinases contained in the human kinase yeast array. In total, 266 human protein kinases and 52\% of the human kinome is represented in the array.

C. Hierarchical clustering of the results of the yeast growth phenotype screen. In each strain, the 266 kinases were binned (0-4) according to the number of conditions in which the kinase caused a growth phenotype. Hierarchical clustering revealed sets of topmost (52), highly (98) and moderately active (116) kinases. Top 30 active kinases causing many growth phenotypes over all conditions-strain pairs are listed.

D. Comparison of the fraction of kinases that result a growth phenotype over all conditions-strain pairs. Kinases are grouped into 179 (67\%) with a yeast ortholog and 87 (33\%) human protein kinases without orthologous yeast kinases. The latter group includes 41 tyrosine kinases and $46 \mathrm{~S} / \mathrm{T}$ kinases which were separated in the analysis. The former group contains both one-to-many and many-to-many orthologous kinases. Tyrosine kinases strongly inhibited yeast growth and human kinases that are orthologous to yeast kinases were more likely to perturb yeast growth than human kinases without a yeast ortholog.

\section{Figure 2: The yeast growth phenotype is a readout for the kinase phosphotransferase activity.}

A. Statistical comparison of the number of yeast growth phenotypes between kinase group and control protein group. In each strain, across all conditions, the percentage of kinases that cause a phenotype upon exogenous expression is significantly higher than the percentage of control proteins, than cause a growth phenotype upon overexpression.

B. Growth comparisons of selected kinases with the kinase-dead mutant match. $24 \mathrm{~h}$ growth curves $\left(\mathrm{OD}_{595}\right)$ from liquid culture of yeast strains (W303) expressing human kinase in the presence or absence of 3.2\% (v/v) DMSO. Upper panel: BUB1: BUB1 wild type, BUB1-KD: NEK6(K821M); middle panel: NEK6: NEK6 wild type, NEK6-KD: NEK6(K74M\&K75M); lower Panel: PKC $\alpha$-ac: PKC $\alpha(\mathrm{A} 25 \mathrm{E})$, PKC $\alpha-K D: P K C \alpha(K 368 R)$

C. Human protein kinases phosphorylate large sets of yeast proteins. Upper panel: In total, 27 human protein kinases showed activity towards yeast proteins visible on western blots through enhanced reactivity with phospho-motif antibodies on yeast proteins in comparison to other human kinases, kinase-dead mutant versions or vector control samples. Lower panel: Examples of western blots with equal amount of whole yeast cell lysate from strains expressing human kinases loaded. When developed 
bioRxiv preprint doi: https://doi.org/10.1101/2021.11.18.469002; this version posted November 19, 2021. The copyright holder for this preprint (which was not certified by peer review) is the author/funder, who has granted bioRxiv a license to display the preprint in perpetuity. It is made available under aCC-BY-NC 4.0 International license.

Kinase array, 11/18/2021

with the indicated phospho-motif recognizing antibodies, immunoreactive bands indicated phosphorylation of yeast proteins.

\section{Figure 3: Representation of active human kinases in the yeast array.}

A. Kinase activity in yeast. Kinase activity is played on the human kinome tree showing that all kinase families contain highly active kinases members.

B. Cancer kinases. The color-coded annotated cancer kinases overlap with of highly active kinases (larger node size) in the array. 168 kinases in the array are linked to at least one cancer type [42].

C. Dark kinases. Dark kinases [10] in the kinome are color coded in purple, the tree shows the overlap of 35 highly active kinases (larger node size) and the total of 72 dark kinases represented in the array.

D. Tissue specific kinases. Normalized proteomics data [43] from 31 tissues show that some kinases are only expressed in a few tissues. Many tissue specific kinases (darker color) belong to the highly active kinases (larger node size) in the yeast array.

D. Low abundant kinases. Average relative expression levels over 31 tissues from PaxDB are color coded. Many kinases with low expression in mammalian cells (darker color) belong to the highly active kinases (larger node size) in the yeast array.

Figures A-E were prepared using CORAL at http://phanstiel-lab.med.unc.edu/CORAL/.

Figure 4: The human kinase yeast array as a tool to identify the kinase(s) modulating a phosphorylation-dependent PPIs.

A. Two distinct cases of phosphorylation-dependent interaction modulation. Loss of interaction: the phosphorylation of one protein (A) by the active kinase results in the loss of interaction with the second protein (B) and therefore in no growth on selective media. Gain of interaction: Co-expression of an active kinase with a $\mathrm{Y} 2 \mathrm{H}$ bait-prey protein pair can lead to phosphorylation of one protein partner (A) promoting the $\mathrm{pS} / \mathrm{T}$-dependent interaction with protein (B). In the phospho-Y2H approach, gain of interaction results in yeast growth on selective media.

B. Systematic phospho-Y2H interaction mating approach to identify the active kinase(s) modulating phosphorylation-dependent PPI. One yeast strain (L40mat $\alpha$ ) co-expressing the interacting bait and prey proteins and was mated against the 266 kinases in the array (L40mata) in a pairwise manner. The growth patterns of the diploid yeast strains that express bait, prey and one kinase from a third plasmid, indicate phospho-modulation of protein interactions.

\section{Figure 5: Identification of human S/T kinases modulating the AAR2-PRP8 protein interaction}

A. Schematic of phospho-dependent interaction of the spliceosomal AAR2 and PRP8. AAR2, a spliceosomal assembly protein, and PRP8 from a stable complex, that dissociates upon phosphorylation of AAR2. PPR8 is then free to bind the spliceosomal interaction partner protein BRR2 [48,49]. This 
bioRxiv preprint doi: https://doi.org/10.1101/2021.11.18.469002; this version posted November 19, 2021. The copyright holder for this preprint (which was not certified by peer review) is the author/funder, who has granted bioRxiv a license to display the preprint in perpetuity. It is made available under aCC-BY-NC 4.0 International license.

Kinase array, 11/18/2021

regulatory interaction switch is thought to be conserved between yeast and human. A protein kinase that can modulate the dissociation of AAR2 from PRP8 is unknown.

B. Superposition of the yeast Aar2 (orange, PDB entry 3SBT; [47]) 3D structure and a homology model of human AAR2 derived from HHpred (marine), based on the yeast Aar2p structure [50]. The inset on the right shows a close-up view of the C-terminal domain, where serines 253 (yeast) and 284 (human) are displayed as sticks. Residues 154-170 and 318-356 of yeast Aar2 as well as residues 1-18, 170-201 and 359-384 of human AAR2 are not shown for clarity.

C. Y2H interaction experiment with human AAR2 as bait and PRP8 as prey. Growth on selective media is abolished when AAR2 carries a S284E phospho-mimicry amino acid substitution. Mutation of second candidate phospho-site, AAR2(T356), does not influence the AAR2-PRP8 protein interaction.

D. Interaction of AAR2 and PRP8 in human cells. HA-tagged PRP8 (aa1755-2335) was co-expressed in HEK293 cells with either wildtype AAR2, AAR2(S284A) or AAR2(S284E) mutant versions. Immunoprecipitation of PRP8 led to a co-precipitation of wild typeAAR2 and phospho-null AAR2(S284A). In contrast, the phospho-mimicry AAR2(S284E) version did not bind PRP8.

E. Results of the phospho-Y2H screen to identify kinases modulating the interaction of AAR2 and PRP8. Growth on selective media (SD5), of strains carring AAR2 bait and PRP8 prey plasmids is reduced through co-expression of either SGK2 or CK2 $\alpha 1$ (CSNK2A1). Growth reduction is visible in a 1:10 dilution series on selective agar (SD5) in comparison to the control media (SD3). Ctrl: non-related kinases.

F. Interaction of AAR2 and PRP8 in human cells in the presences of SGK and CK2 $\alpha 1$ kinases. Experiment as in D. Co-expression of wild type SGK2 and CK2 $\alpha 1$ reduces the amount of AAR2 coimmunoprecipitated with RPR8.

\section{Figure 6: Identification of human $S / T$ kinases modulating the ER $\alpha-14-3-3$ phosphorylation-dependent interaction}

A. Schematic of phospho-dependent interaction of the estrogen receptor ER $\alpha$ with 14-3-3 3 . Phosphorylation of ER $\alpha$ promotes its interaction with 14-3-3 proteins. This interaction removes ER $\alpha$ from the E2-stimulated ER $\alpha$ dimerization and as a consequence inhibits ER $\alpha$ chromatin interactions and gene expression. A protein kinase that can modulate the binding of ER $\alpha$ to 14-3-3 proteins is unknown.

B. Results of the phospho-Y2H screen to identify kinases modulating the interaction of the ER $\alpha$ with

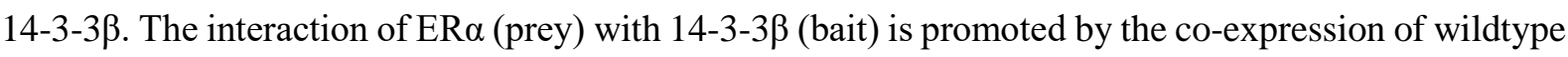
kinases of PAK5, CDK17, BUB1 and NEK6, for three biological replicas visible by the yeast growth on selective media in comparison to the control. The coexpression of the kinase-dead mutants of PAK5 and CDK17 also promoted the interaction of $\mathrm{ER} \alpha$ and 14-3-3 $\beta$. In contrast the kinase-dead mutant versions of BUB1(K821M) and NEK6(K74M\&K75M) did not promote the Y2H interaction. 
C. Phosphorylation of ER $\alpha$ in mammalian cells. ER $\alpha$ was co-expressed with the indicated wildtype kinases or kinase-dead versions in HEK293 cells and immunoprecipitated. Phosphorylation status of ER $\alpha$ was analyzed with an in-gel phosphostain (Pro-Q ${ }^{\circledR}$ Diamond phosphoprotein gel stain, Invitrogen), relative to the whole protein stain (SYPRO®Ruby protein gel stain, Invitrogen).

D. Interaction of ER $\alpha$ and 14-3-3 $\beta$ in a GST pull-down assay. GST-tagged 14-3-3 $\beta$ was expressed in E. coli and immobilized on beads. PA-tagged ER $\alpha$ was co-expressed with either wildtype PAK5 or NEK6, the kinase-dead (KD) version or without a kinase in HEK293 cells. Immobilized 14-3-3 $\beta$ was used to pull PA-tagged ER $\alpha$ from the HEK lysates. Co-precipitation of ER $\alpha$ was successful in the presence of wild kinases, but not in their absence or with kinase-dead mutant versions.

E. Effect of NEK6 co-expression on ER $\alpha$ gene activation. Relative luciferase activity of ER $\alpha$ in the presence and absence of $1 \mathrm{nM}$ E2 (17 $\beta$-estradiol) was measured. A dose-dependent reduction (ng plasmid transfected) in E2-Ero-dependent luciferase expression was observed in HEK293T, MCF-7 and US-OS cancer cell lines. This effect was not observed with the NEK6(K74M\&K75M) kinase-dead version. Error bars indicate SD of triplicate transfections.

\section{Supplementary Table 1: Conditions}

Information about 73 different conditions (33 unique treatments) which were successfully evaluated for at least one of the four strains. A total 243 condition - strain pairs were considered.

\section{Supplementary Table 2: Kinases}

Information about the 266 human kinases assayed for activity in yeast. Activity ranks are based on binning the number of conditions where growth reduction was observed in each strain (0-4) followed by clustering (Figure 1). Annotations shown in Figure 3 are listed.

\section{Supplementary Figure 1: Luciferase based Co-immunoprecipitation experiments}

Results of the LUMIER assay with 14-3-3 $\beta$ (tagged with firefly luciferase) and the indicated kinases (protein A tagged) identified in the Y2H-Screen. CDK16 is a known interaction partner of 14-3-3 $\beta$ and served as positive control (light grey). Error bars indicate SD of triplicate transfections. 


\section{Literature}

1. Ubersax JA, Ferrell JE: Mechanisms of specificity in protein phosphorylation. Nature reviews. Molecular cell biology 2007;8(7):530-41, doi:10.1038/nrm2203.

2. Manning G, Whyte DB, Martinez R, Hunter T, Sudarsanam S: The protein kinase complement of the human genome. Science (New York, N.Y.) 2002;298(5600):1912-34, doi:10.1126/science.1075762.

3. Ochoa D, Jonikas M, Lawrence RT, El Debs B, Selkrig J, Typas A, Villén J, Santos SD, Beltrao P: An atlas of human kinase regulation. Molecular systems biology 2016;12(12):888, doi:10.15252/msb.20167295.

4. Tan C, Bodenmiller B, Pasculescu A, Jovanovic M, Hengartner MO, Jørgensen C, Bader GD, Aebersold R, Pawson T, Linding R: Comparative analysis reveals conserved protein phosphorylation networks implicated in multiple diseases. Science signaling 2009;2(81):ra39, doi:10.1126/scisignal.2000316.

5. Corwin T, Woodsmith J, Apelt F, Fontaine J-F, Meierhofer D, Helmuth J, Grossmann A, AndradeNavarro MA, Ballif BA, Stelzl U: Defining Human Tyrosine Kinase Phosphorylation Networks Using Yeast as an In Vivo Model Substrate. Cell systems 2017;5(2):128-139.e4, doi:10.1016/j.cels.2017.08.001.

6. Needham EJ, Parker BL, Burykin T, James DE, Humphrey SJ: Illuminating the dark phosphoproteome. Science signaling 2019;12(565), doi:10.1126/scisignal.aau8645.

7. Campbell J, Ryan CJ, Brough R, Bajrami I, Pemberton HN, Chong IY, Costa-Cabral S, Frankum J, Gulati A, Holme H et al.: Large-Scale Profiling of Kinase Dependencies in Cancer Cell Lines. Cell reports 2016;14(10):2490-501, doi:10.1016/j.celrep.2016.02.023.

8. Cohen P, Cross D, Jänne PA: Kinase drug discovery 20 years after imatinib: progress and future directions. Nature reviews. Drug discovery 2021;20(7):551-69, doi:10.1038/s41573-02100195-4.

9. Fedorov O, Müller S, Knapp S: The (un)targeted cancer kinome. Nature chemical biology 2010;6(3):166-9, doi:10.1038/nchembio.297.

10. Berginski ME, Moret N, Liu C, Goldfarb D, Sorger PK, Gomez SM: The Dark Kinase Knowledgebase: an online compendium of knowledge and experimental results of understudied kinases. Nucleic acids research 2021;49(D1):D529-D535, doi:10.1093/nar/gkaa853.

11. Zhang J, Allen MD: FRET-based biosensors for protein kinases: illuminating the kinome. Molecular bioSystems 2007;3(11):759-65, doi:10.1039/b706628g.

12. Shults MD, Janes KA, Lauffenburger DA, Imperiali B: A multiplexed homogeneous fluorescence-based assay for protein kinase activity in cell lysates. Nature methods 2005;2(4):277-83, doi:10.1038/NMETH747. 
bioRxiv preprint doi: https://doi.org/10.1101/2021.11.18.469002; this version posted November 19, 2021. The copyright holder for this preprint (which was not certified by peer review) is the author/funder, who has granted bioRxiv a license to display the preprint in perpetuity. It is made available under aCC-BY-NC 4.0 International license.

13. Schmitt DL, Mehta S, Zhang J: Illuminating the kinome: Visualizing real-time kinase activity in biological systems using genetically encoded fluorescent protein-based biosensors. Current opinion in chemical biology 2020;54:63-9, doi:10.1016/j.cbpa.2019.11.005.

14. Enzler F, Tschaikner P, Schneider R, Stefan E: KinCon: Cell-based recording of full-length kinase conformations. IUBMB life 2020;72(6):1168-74, doi:10.1002/iub.2241.

15. Elledge SJ, Spottswood MR: A new human p34 protein kinase, CDK2, identified by complementation of a cdc28 mutation in Saccharomyces cerevisiae, is a homolog of Xenopus Eg1. The EMBO journal 1991;10(9):2653-9.

16. Ninomiya-Tsuji J, Nomoto S, Yasuda H, Reed SI, Matsumoto K: Cloning of a human cDNA encoding a CDC2-related kinase by complementation of a budding yeast cdc28 mutation. Proceedings of the National Academy of Sciences of the United States of America 1991;88(20):9006-10.

17. Yang F, Sun S, Tan G, Costanzo M, Hill DE, Vidal M, Andrews BJ, Boone C, Roth FP: Identifying pathogenicity of human variants via paralog-based yeast complementation. PLoS genetics 2017;13(5):e1006779, doi:10.1371/journal.pgen.1006779.

18. Nada S, Okada M, MacAuley A, Cooper JA, Nakagawa H: Cloning of a complementary DNA for a protein-tyrosine kinase that specifically phosphorylates a negative regulatory site of p60c-src. Nature 1991;351(6321):69-72, doi:10.1038/351069a0.

19. Grossmann A, Benlasfer N, Birth P, Hegele A, Wachsmuth F, Apelt L, Stelzl U: Phosphotyrosine dependent protein-protein interaction network. Molecular systems biology 2015;11(3):794, doi:10.15252/msb.20145968.

20. Brugge JS, Jarosik G, Andersen J, Queral-Lustig A, Fedor-Chaiken M, Broach JR: Expression of Rous sarcoma virus transforming protein pp60v-src in Saccharomyces cerevisiae cells. Molecular and cellular biology 1987;7(6):2180-7.

21. Kornbluth S, Jove R, Hanafusa H: Characterization of avian and viral p60src proteins expressed in yeast. Proceedings of the National Academy of Sciences of the United States of America 1987;84(13):4455-9.

22. Cooper JA, MacAuley A: Potential positive and negative autoregulation of p60c-src by intermolecular autophosphorylation. Proceedings of the National Academy of Sciences of the United States of America 1988;85(12):4232-6.

23. Ahler E, Register AC, Chakraborty S, Fang L, Dieter EM, Sitko KA, Vidadala RSR, Trevillian BM, Golkowski M, Gelman H et al.: A Combined Approach Reveals a Regulatory Mechanism Coupling Src's Kinase Activity, Localization, and Phosphotransferase-Independent Functions. Molecular cell 2019;74(2):393-408.e20, doi:10.1016/j.molcel.2019.02.003.

24. Boschelli F, Uptain SM, Lightbody JJ: The lethality of p60v-src in Saccharomyces cerevisiae and the activation of $\mathrm{p34CDC28}$ kinase are dependent on the integrity of the SH2 domain. Journal of cell science 1993;105 (Pt 2):519-28. 
bioRxiv preprint doi: https://doi.org/10.1101/2021.11.18.469002; this version posted November 19, 2021. The copyright holder for this preprint (which was not certified by peer review) is the author/funder, who has granted bioRxiv a license to display the preprint in perpetuity. It is made available under aCC-BY-NC 4.0 International license.

25. Florio M, Wilson LK, Trager JB, Thorner J, Martin GS: Aberrant protein phosphorylation at tyrosine is responsible for the growth-inhibitory action of pp60v-src expressed in the yeast Saccharomyces cerevisiae. Molecular biology of the cell 1994;5(3):283-96.

26. Kritzer JA, Freyzon Y, Lindquist S: Yeast can accommodate phosphotyrosine. V-Src toxicity in yeast arises from a single disrupted pathway. FEMS yeast research 2018, doi:10.1093/femsyr/foy027.

27. Alessi DR, Andjelkovic M, Caudwell B, Cron P, Morrice N, Cohen P, Hemmings BA: Mechanism of activation of protein kinase $\mathrm{B}$ by insulin and IGF-1. The EMBO journal 1996;15(23):6541-51.

28. Rodríguez-Escudero I, Andrés-Pons A, Pulido R, Molina M, Cid VJ: Phosphatidylinositol 3kinase-dependent activation of mammalian protein kinase B/Akt in Saccharomyces cerevisiae, an in vivo model for the functional study of Akt mutations. The Journal of biological chemistry 2009;284(20):13373-83, doi:10.1074/jbc.M807867200.

29. Sekigawa M, Kunoh T, Wada S-I, Mukai Y, Ohshima K, Ohta S, Goshima N, Sasaki R, Mizukami $\mathrm{T}$ : Comprehensive screening of human genes with inhibitory effects on yeast growth and validation of a yeast cell-based system for screening chemicals. Journal of biomolecular screening 2010;15(4):368-78, doi:10.1177/1087057110363822.

30. Kim J-H, Seo Y, Jo M, Jeon H, Lee W-H, Yachie N, Zhong Q, Vidal M, Roth FP, Suk K: YeastBased Genetic Interaction Analysis of Human Kinome. Cells 2020;9(5), doi:10.3390/cells9051156.

31. Hillenmeyer ME, Fung E, Wildenhain J, Pierce SE, Hoon S, Lee W, Proctor M, St Onge RP, Tyers $\mathrm{M}$, Koller $\mathrm{D}$ et al.: The chemical genomic portrait of yeast: uncovering a phenotype for all genes. Science (New York, N.Y.) 2008;320(5874):362-5, doi:10.1126/science.1150021.

32. Dowell RD, Ryan O, Jansen A, Cheung D, Agarwala S, Danford T, Bernstein DA, Rolfe PA, Heisler LE, Chin B et al.: Genotype to phenotype: a complex problem. Science (New York, N.Y.) 2010;328(5977):469, doi:10.1126/science.1189015.

33. Woodsmith J, Stelzl U: Studying post-translational modifications with protein interaction networks. Current opinion in structural biology 2014;24:34-44, doi:10.1016/j.sbi.2013.11.009.

34. Filteau M, Vignaud H, Rochette S, Diss G, Chrétien A-È, Berger CM, Landry CR: Multi-scale perturbations of protein interactomes reveal their mechanisms of regulation, robustness and insights into genotype-phenotype maps. Briefings in functional genomics 2016;15(2):130-7, doi:10.1093/bfgp/elv043.

35. Brachmann CB, Davies A, Cost GJ, Caputo E, Li J, Hieter P, Boeke JD: Designer deletion strains derived from Saccharomyces cerevisiae S288C. A useful set of strains and plasmids for PCR-mediated gene disruption and other applications. Yeast (Chichester, England) 1998;14(2):115-32, doi:10.1002/(SICI)1097-0061(19980130)14:2<115:AID-YEA204>3.0.CO;22. 
36. Winston F, Dollard C, Ricupero-Hovasse SL: Construction of a set of convenient Saccharomyces cerevisiae strains that are isogenic to S288C. Yeast (Chichester, England) 1995;11(1):53-5, doi:10.1002/yea.320110107.

37. Goehler H, Lalowski M, Stelzl U, Waelter S, Stroedicke M, Worm U, Droege A, Lindenberg KS, Knoblich M, Haenig C et al.: A protein interaction network links GIT1, an enhancer of huntingtin aggregation, to Huntington's disease. Molecular cell 2004;15(6):853-65, doi:10.1016/j.molcel.2004.09.016.

38. Worseck JM, Grossmann A, Weimann M, Hegele A, Stelzl U: A stringent yeast two-hybrid matrix screening approach for protein-protein interaction discovery. Methods in molecular biology (Clifton, N.J.) 2012;812:63-87, doi:10.1007/978-1-61779-455-1_4.

39. Ralser M, Kuhl H, Ralser M, Werber M, Lehrach H, Breitenbach M, Timmermann B: The Saccharomyces cerevisiae W303-K6001 cross-platform genome sequence. Insights into ancestry and physiology of a laboratory mutt. Open biology 2012;2(8):120093, doi:10.1098/rsob.120093.

40. Newman RH, Hu J, Rho H-S, Xie Z, Woodard C, Neiswinger J, Cooper C, Shirley M, Clark HM, $\mathrm{Hu} \mathrm{S}$ et al.: Construction of human activity-based phosphorylation networks. Molecular systems biology 2013;9:655, doi:10.1038/msb.2013.12.

41. Tan C, Pasculescu A, Lim WA, Pawson T, Bader GD, Linding R: Positive selection of tyrosine loss in metazoan evolution. Science (New York, N.Y.) 2009;325(5948):1686-8, doi:10.1126/science.1174301.

42. Piñero J, Saüch J, Sanz F, Furlong LI: The DisGeNET cytoscape app: Exploring and visualizing disease genomics data. Computational and structural biotechnology journal 2021;19:2960-7, doi:10.1016/j.csbj.2021.05.015.

43. Wang M, Herrmann CJ, Simonovic M, Szklarczyk D, Mering C von: Version 4.0 of PaxDb: Protein abundance data, integrated across model organisms, tissues, and cell-lines. Proteomics 2015;15(18):3163-8, doi:10.1002/pmic.201400441.

44. Moesslacher CS, Kohlmayr JM, Stelzl U: Exploring absent protein function in yeast: assaying post translational modification and human genetic variation. Microbial cell (Graz, Austria) 2021;8(8):164-83, doi:10.15698/mic2021.08.756.

45. Nishi H, Hashimoto K, Panchenko AR: Phosphorylation in protein-protein binding: effect on stability and function. Structure (London, England 1993) 2011;19(12):1807-15, doi:10.1016/j.str.2011.09.021.

46. Tudor CO, Ross KE, Li G, Vijay-Shanker K, Wu CH, Arighi CN: Construction of phosphorylation interaction networks by text mining of full-length articles using the eFIP system. Database the journal of biological databases and curation 2015;2015, doi:10.1093/database/bav020.

47. Weber G, Cristão VF, L Alves F de, Santos KF, Holton N, Rappsilber J, Beggs JD, Wahl MC: Mechanism for Aar2p function as a U5 snRNP assembly factor. Genes \& development 2011;25(15):1601-12, doi:10.1101/gad.635911. 
bioRxiv preprint doi: https://doi.org/10.1101/2021.11.18.469002; this version posted November 19, 2021. The copyright holder for this preprint (which was not certified by peer review) is the author/funder, who has granted bioRxiv a license to display the preprint in perpetuity. It is made available under aCC-BY-NC 4.0 International license.

48. Weber G, Cristão VF, Santos KF, Jovin SM, Heroven AC, Holton N, Lührmann R, Beggs JD, Wahl MC: Structural basis for dual roles of Aar2p in U5 snRNP assembly. Genes \& development 2013;27(5):525-40, doi:10.1101/gad.213207.113.

49. Galej WP, Oubridge C, Newman AJ, Nagai K: Crystal structure of Prp8 reveals active site cavity of the spliceosome. Nature 2013;493(7434):638-43, doi:10.1038/nature11843.

50. Santos K, Preussner M, Heroven AC, Weber G: Crystallization and biochemical characterization of the human spliceosomal Aar2-Prp8(RNaseH) complex. Acta crystallographica. Section F, Structural biology communications 2015;71(Pt 11):1421-8, doi:10.1107/S2053230X15019202.

51. Hornbeck PV, Kornhauser JM, Tkachev S, Zhang B, Skrzypek E, Murray B, Latham V, Sullivan M: PhosphoSitePlus: a comprehensive resource for investigating the structure and function of experimentally determined post-translational modifications in man and mouse. Nucleic acids research 2012;40(Database issue):D261-70, doi:10.1093/nar/gkr1122.

52. Hegele A, Kamburov A, Grossmann A, Sourlis C, Wowro S, Weimann M, Will CL, Pena V, Lührmann R, Stelzl U: Dynamic protein-protein interaction wiring of the human spliceosome. Molecular cell 2012;45(4):567-80, doi:10.1016/j.molcel.2011.12.034.

53. Vinayagam A, Stelzl U, Wanker EE: Repeated two-hybrid screening detects transient proteinprotein interactions. Theor Chem Acc 2010;125(3-6):613-9, doi:10.1007/s00214-009-0651-8.

54. Vries-van Leeuwen IJ de, da Costa Pereira D, Flach KD, Piersma SR, Haase C, Bier D, Yalcin Z, Michalides R, Feenstra KA, Jiménez CR et al.: Interaction of 14-3-3 proteins with the estrogen receptor alpha $\mathbf{F}$ domain provides a drug target interface. Proceedings of the National Academy of Sciences of the United States of America 2013;110(22):8894-9, doi:10.1073/pnas.1220809110.

55. Tinti M, Madeira F, Murugesan G, Hoxhaj G, Toth R, Mackintosh C: ANIA: ANnotation and Integrated Analysis of the 14-3-3 interactome. Database the journal of biological databases and curation 2014;2014:bat085, doi:10.1093/database/bat085.

56. Hall JM, McDonnell DP: The estrogen receptor beta-isoform (ERbeta) of the human estrogen receptor modulates ERalpha transcriptional activity and is a key regulator of the cellular response to estrogens and antiestrogens. Endocrinology 1999;140(12):5566-78, doi:10.1210/endo.140.12.7179.

57. Elkins JM, Fedele V, Szklarz M, Abdul Azeez KR, Salah E, Mikolajczyk J, Romanov S, Sepetov N, Huang X-P, Roth BL et al.: Comprehensive characterization of the Published Kinase Inhibitor Set. Nature biotechnology 2016;34(1):95-103, doi:10.1038/nbt.3374.

58. Anastassiadis T, Deacon SW, Devarajan K, Ma H, Peterson JR: Comprehensive assay of kinase catalytic activity reveals features of kinase inhibitor selectivity. Nature biotechnology 2011;29(11):1039-45, doi:10.1038/nbt.2017.

59. Taipale M, Krykbaeva I, Whitesell L, Santagata S, Zhang J, Liu Q, Gray NS, Lindquist S: Chaperones as thermodynamic sensors of drug-target interactions reveal kinase inhibitor specificities in living cells. Nature biotechnology 2013;31(7):630-7, doi:10.1038/nbt.2620. 
60. Wahl MC, Will CL, Lührmann R: The spliceosome: design principles of a dynamic RNP machine. Cell 2009;136(4):701-18, doi:10.1016/j.cell.2009.02.009.

61. Absmeier E, Rosenberger L, Apelt L, Becke C, Santos KF, Stelzl U, Wahl MC: A noncanonical PWI domain in the $\mathbf{N}$-terminal helicase-associated region of the spliceosomal Brr2 protein. Acta crystallographica. Section D, Biological crystallography 2015;71(Pt 4):762-71, doi:10.1107/S1399004715001005.

62. Kobayashi T, Cohen P: Activation of serum- and glucocorticoid-regulated protein kinase by agonists that activate phosphatidylinositide 3-kinase is mediated by 3-phosphoinositidedependent protein kinase-1 (PDK1) and PDK2. The Biochemical journal 1999;339 (Pt 2):31928.

63. Pao AC: SGK regulation of renal sodium transport. Current opinion in nephrology and hypertension 2012;21(5):534-40, doi:10.1097/MNH.0b013e32835571be.

64. Ranzuglia V, Lorenzon I, Pellarin I, Sonego M, Dall'Acqua A, D'Andrea S, Lovisa S, Segatto I, Coan M, Polesel J et al.: Serum- and glucocorticoid- inducible kinase 2, SGK2, is a novel autophagy regulator and modulates platinum drugs response in cancer cells. Oncogene 2020;39(40):6370-86, doi:10.1038/s41388-020-01433-6.

65. Nuñez de Villavicencio-Diaz T, Rabalski AJ, Litchfield DW: Protein Kinase CK2: Intricate Relationships within Regulatory Cellular Networks. Pharmaceuticals (Basel, Switzerland) 2017;10(1), doi:10.3390/ph10010027.

66. Filhol $\mathrm{O}$, Cochet $\mathrm{C}$ : Protein kinase CK2 in health and disease: Cellular functions of protein kinase CK2: a dynamic affair. Cellular and molecular life sciences CMLS 2009;66(1112):1830-9, doi:10.1007/s00018-009-9151-1.

67. Meggio F, Pinna LA: One-thousand-and-one substrates of protein kinase CK2? FASEB journal official publication of the Federation of American Societies for Experimental Biology 2003;17(3):349-68, doi:10.1096/fj.02-0473rev.

68. Dörr J, Kartarius S, Götz C, Montenarh M: Contribution of the individual subunits of protein kinase CK2 and of hPrp3p to the splicing process. Molecular and cellular biochemistry 2008;316(1-2):187-93, doi:10.1007/s11010-008-9820-7.

69. Lehnert S, Götz C, Kartarius S, Schäfer B, Montenarh M: Protein kinase CK2 interacts with the splicing factor hPrp3p. Oncogene 2008;27(17):2390-400, doi:10.1038/sj.onc.1210882.

70. Trembley JH, Tatsumi S, Sakashita E, Loyer P, Slaughter CA, Suzuki H, Endo H, Kidd VJ, Mayeda A: Activation of pre-mRNA splicing by human RNPS1 is regulated by CK2 phosphorylation. Molecular and cellular biology 2005;25(4):1446-57, doi:10.1128/MCB.25.4.1446-1457.2005.

71. Anbalagan M, Rowan BG: Estrogen receptor alpha phosphorylation and its functional impact in human breast cancer. Molecular and cellular endocrinology 2015;418 Pt 3:264-72, doi:10.1016/j.mce.2015.01.016. 
72. Kang J, Yang M, Li B, Qi W, Zhang C, Shokat KM, Tomchick DR, Machius M, Yu H: Structure and substrate recruitment of the human spindle checkpoint kinase Bub1. Molecular cell 2008;32(3):394-405, doi:10.1016/j.molcel.2008.09.017.

73. Cau J, Faure S, Comps M, Delsert C, Morin N: A novel p21-activated kinase binds the actin and microtubule networks and induces microtubule stabilization. The Journal of cell biology 2001;155(6):1029-42, doi:10.1083/jcb.200104123.

74. Huang S, Zhu Y, Wang C, Li X, Cui X, Tu S, You L, Fu J, Chen Z, Hu W et al.: PAK5 facilitates the proliferation, invasion and migration in colorectal cancer cells. Cancer medicine 2020;9(13):4777-90, doi:10.1002/cam4.3084.

75. Malumbres M, Harlow E, Hunt T, Hunter T, Lahti JM, Manning G, Morgan DO, Tsai L-H, Wolgemuth DJ: Cyclin-dependent kinases: a family portrait. Nature cell biology 2009;11(11):1275-6, doi:10.1038/ncb1109-1275.

76. Yin M-J, Shao L, Voehringer D, Smeal T, Jallal B: The serine/threonine kinase Nek6 is required for cell cycle progression through mitosis. The Journal of biological chemistry 2003;278(52):52454-60, doi:10.1074/jbc.m308080200.

77. O'Regan L, Fry AM: The Nek6 and Nek7 protein kinases are required for robust mitotic spindle formation and cytokinesis. Molecular and cellular biology 2009;29(14):3975-90, doi:10.1128/MCB.01867-08.

78. van de Kooij B, Creixell P, van Vlimmeren A, Joughin BA, Miller CJ, Haider N, Simpson CD, Linding R, Stambolic V, Turk BE et al.: Comprehensive substrate specificity profiling of the human Nek kinome reveals unexpected signaling outputs. eLife 2019;8, doi:10.7554/eLife.44635.

79. Harris LK, Frumm SM, Bishop AC: A general assay for monitoring the activities of protein tyrosine phosphatases in living eukaryotic cells. Analytical biochemistry 2013;435(2):99-105, doi:10.1016/j.ab.2012.12.025.

80. Koyama M, Saito S, Nakagawa R, Katsuyama I, Hatanaka M, Yamamoto T, Arakawa T, Tokunag M: Expression of human tyrosine kinase, Lck, in yeast Saccharomyces cerevisiae: growth suppression and strategy for inhibitor screening. Protein and peptide letters 2006;13(9):91520.

81. Woodsmith J, Casado-Medrano V, Benlasfer N, Eccles RL, Hutten S, Heine CL, Thormann V, Abou-Ajram C, Rocks O, Dormann D et al.: Interaction modulation through arrays of clustered methyl-arginine protein modifications. Life science alliance 2018;1(5):e201800178, doi:10.26508/1sa.201800178. 
bioRxiv preprint doi: https://doi.org/10.1101/2021.11.18.469бodgtib/ersibn posted November 19, 2021. The copyright holder for this preprint (which was not certified by peer review) is the author/funder, who has granted bioRxiv a license to display the preprint in perpetuity. It is made available under aCC-BY-NC 4.0 International license.

A
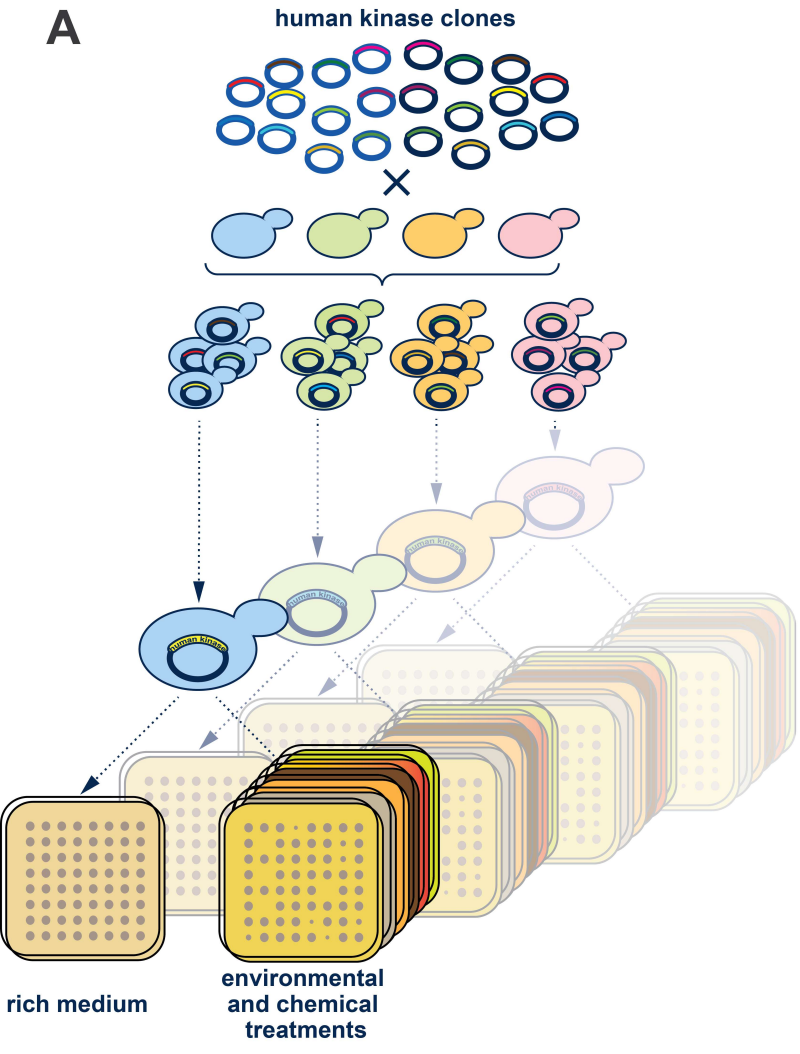

C

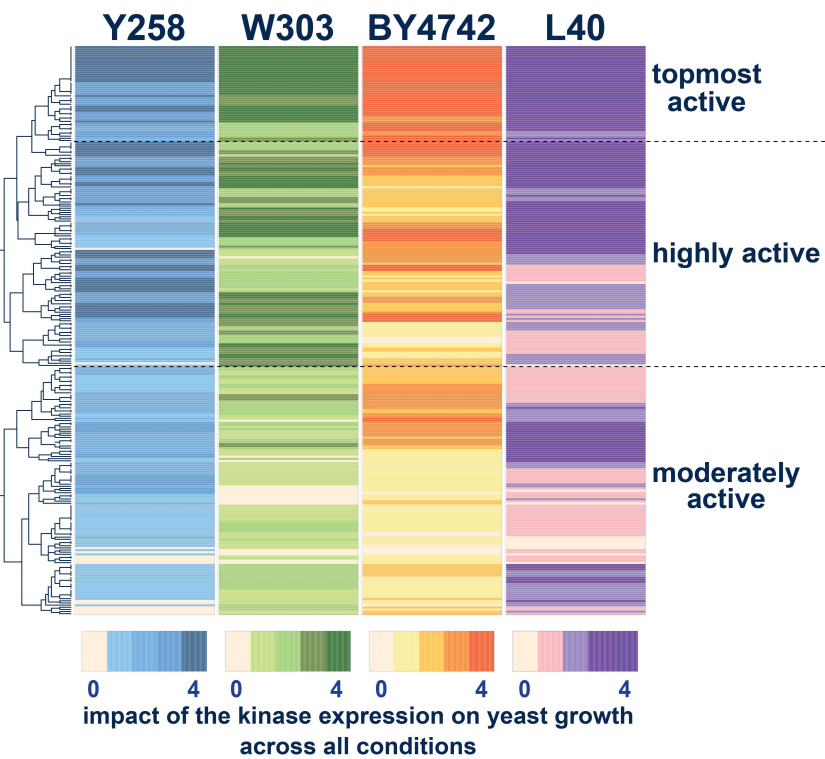

Top 30 active kinases in yeast

\begin{tabular}{|c|c|c|c|c|}
\hline AGC & CAMK & CMGC & TK & Other \\
\hline $\begin{array}{l}\text { PKCa } \\
\text { PKCE } \\
\text { PKAA }\end{array}$ & $\begin{array}{l}\text { MARK3 } \\
\text { PIM2 } \\
\text { SSTK } \\
\text { STK333 } \\
\text { TSSK3 }\end{array}$ & $\begin{array}{l}\text { p38a } \\
\text { p383 } \\
\text { pDK2 } \\
\text { CDK2 } \\
\text { CDK3 } \\
\text { CDK17 } \\
\text { CDL3 } \\
\text { CYRK1B } \\
\text { DYRK4 }\end{array}$ & $\begin{array}{l}\text { FAK } \\
\text { FER } \\
\text { FGR } \\
\text { FYN } \\
\text { HCK } \\
\text { SRC }\end{array}$ & $\begin{array}{l}\text { ALK7 } \\
\text { AURKA } \\
\text { CK2A2 } \\
\text { MAPR25 } \\
\text { NEK6 } \\
\text { PBK } \\
\text { PIPK } \\
\text { RCK2 }\end{array}$ \\
\hline
\end{tabular}

B
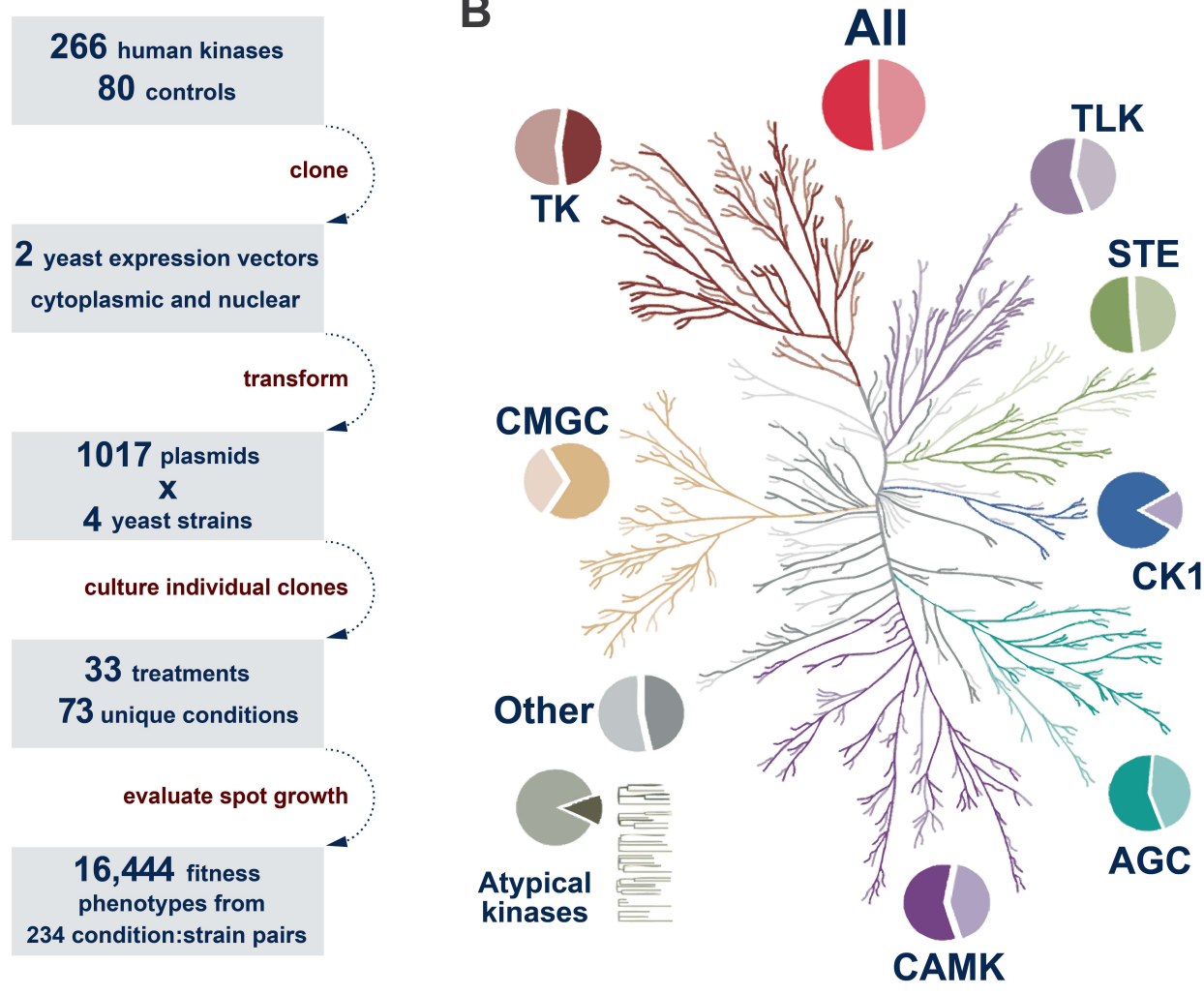

D

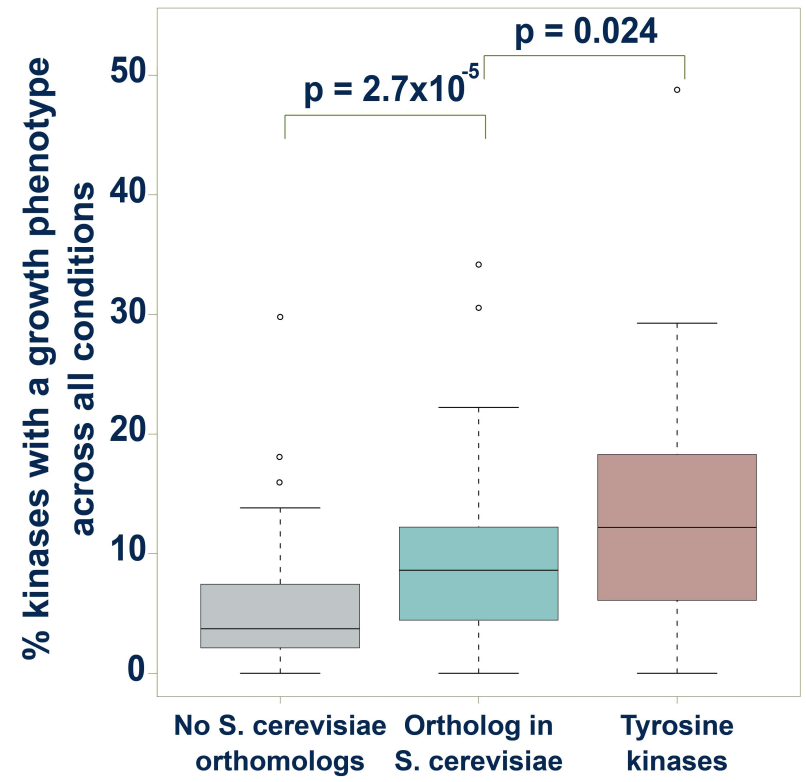


A

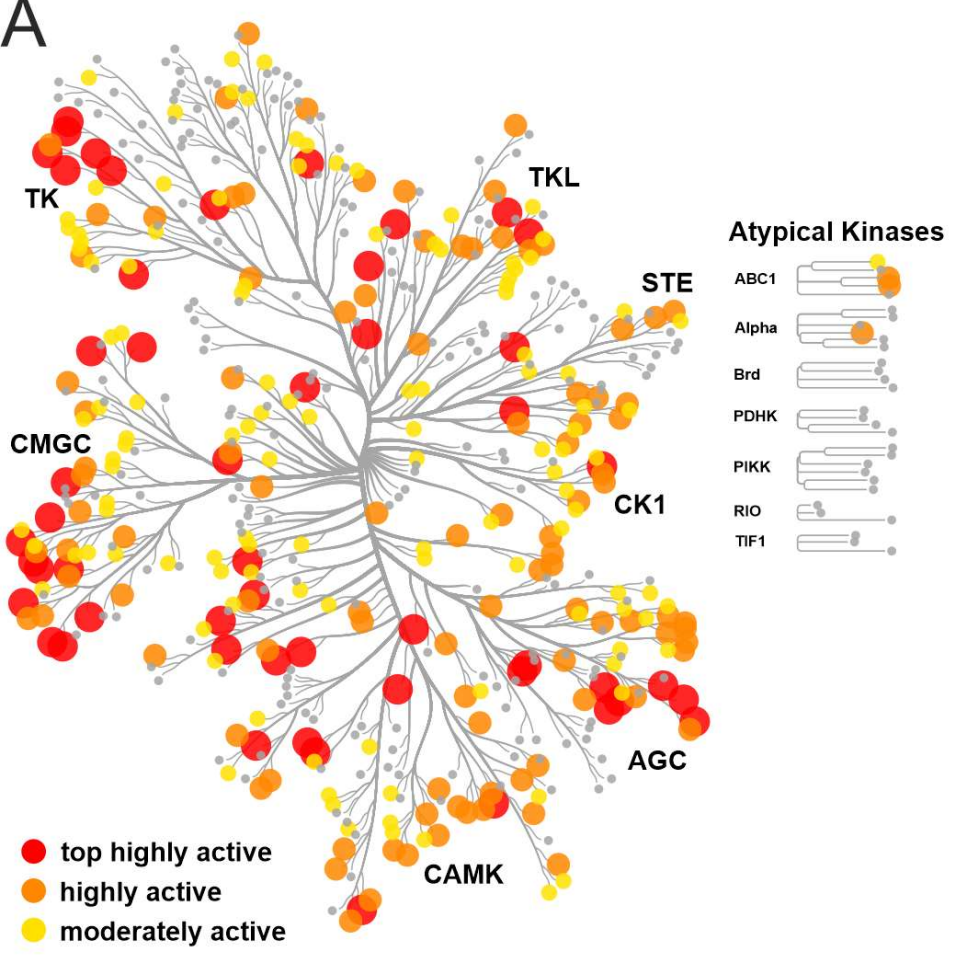

Kinase activity in yeast
B

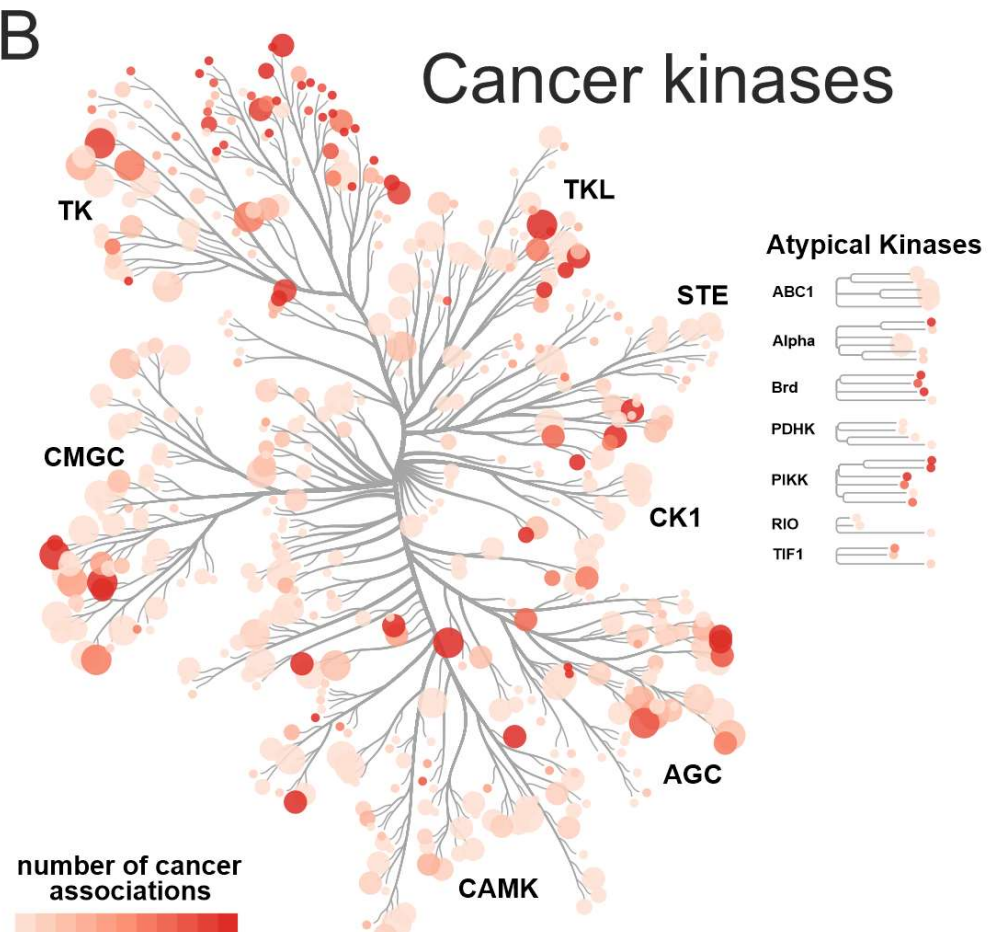

C

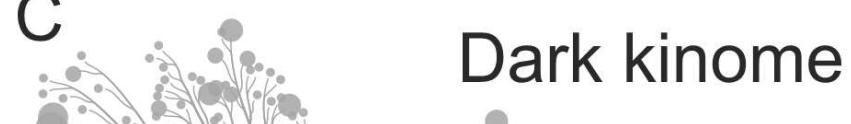

,

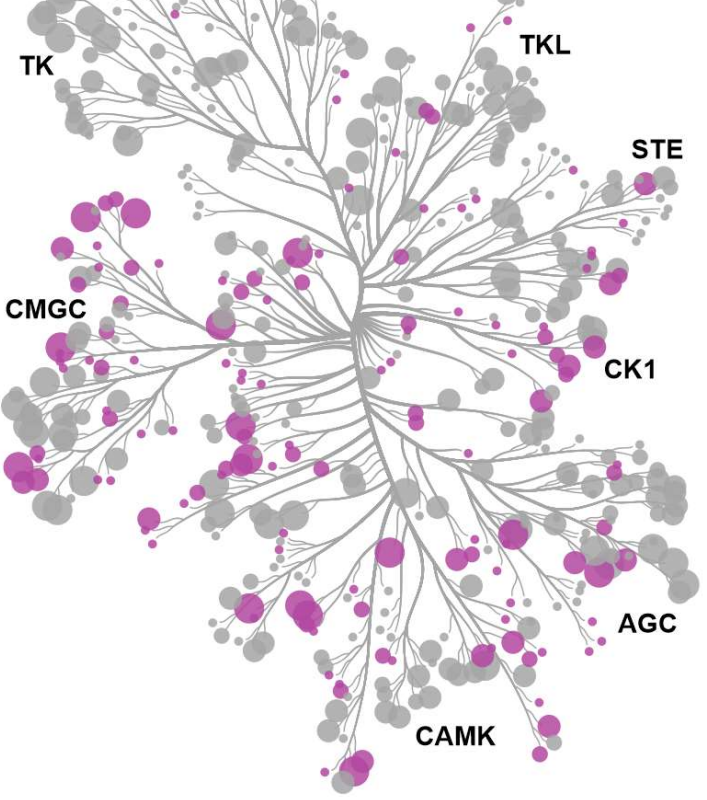

Atypical Kinases

$$
\text { ABC }
$$

Apha $=\vec{E}_{8}^{8}$

$$
\begin{aligned}
& \text { PDHK } \\
& \text { PIKK } \\
& \text { RIO } 1 \text { 8 }
\end{aligned}
$$

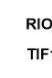

$\begin{array}{lll}0 & 5 & >10\end{array}$

D $\quad$ Tissue specific ․․․

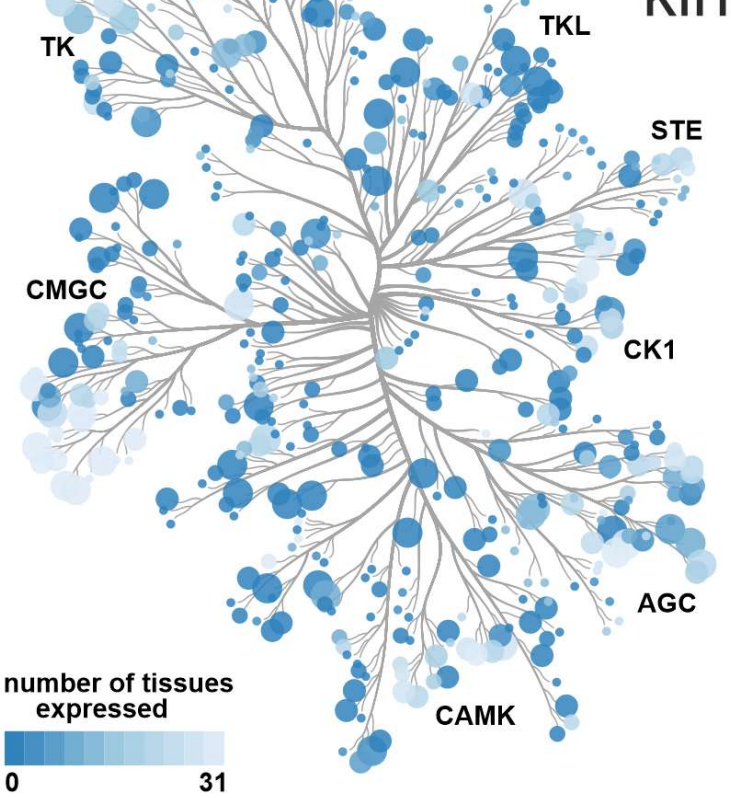

Atypical Kinases

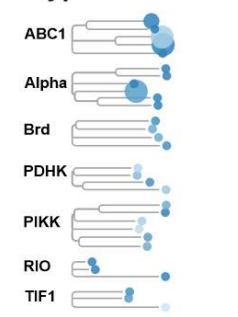

E

\section{Low abundant}

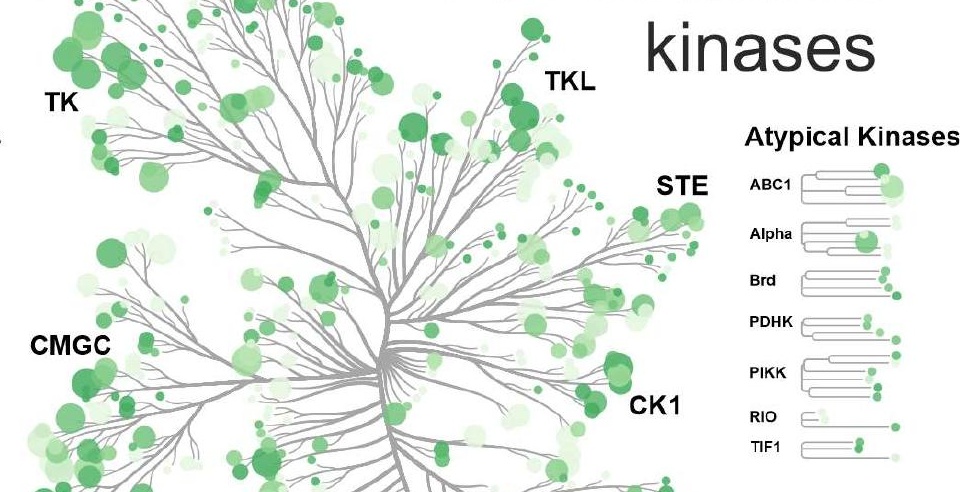

\section{Node Size}

top highly active

highly active

- moderately active

not in the array

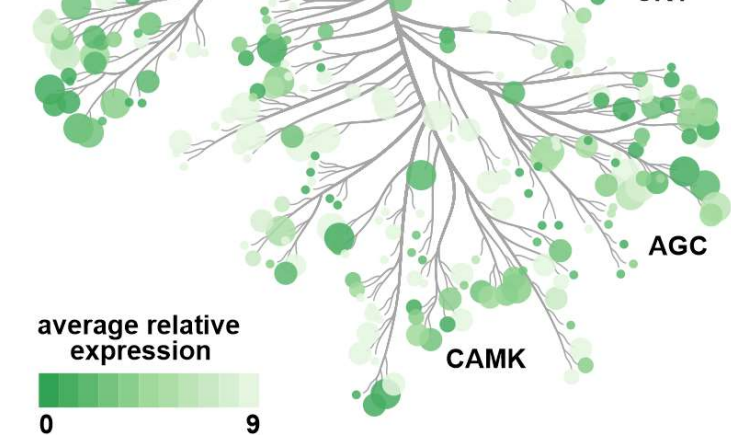



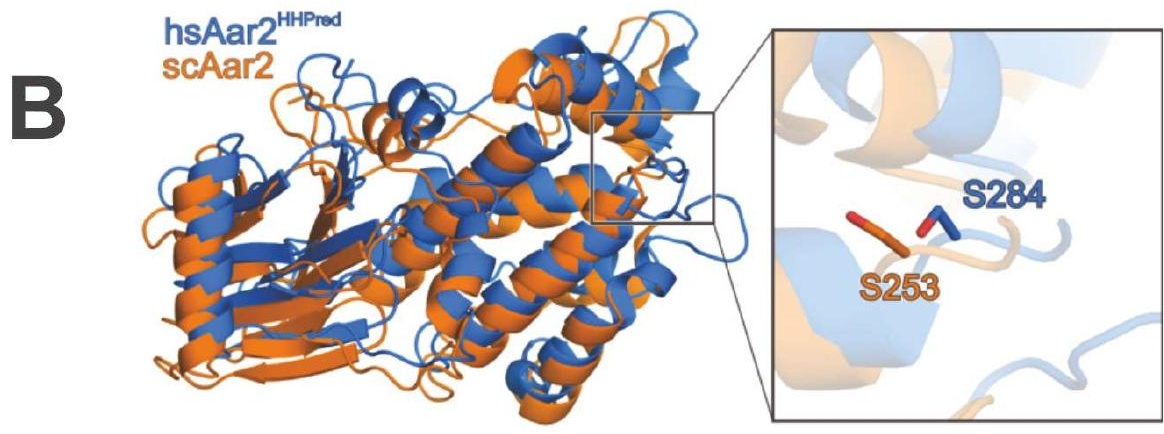

\section{unknown kinase(s)}

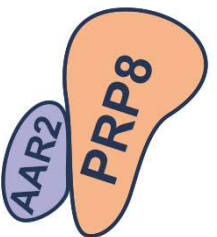
AAR2

(P)
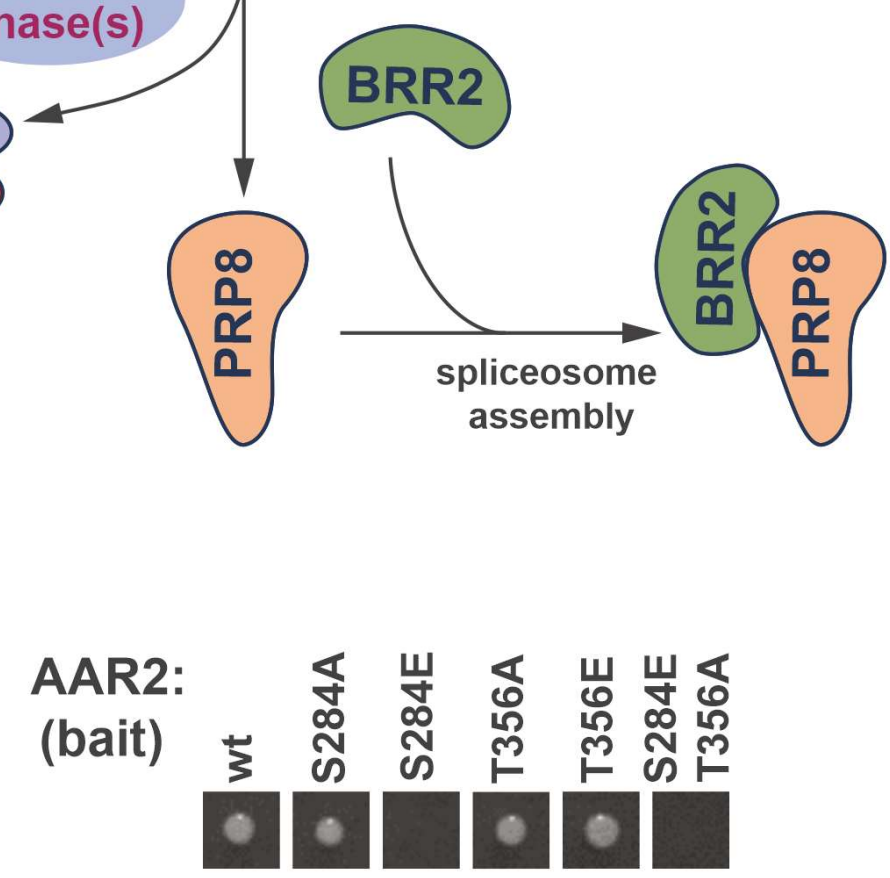

PRPF8 (prey)

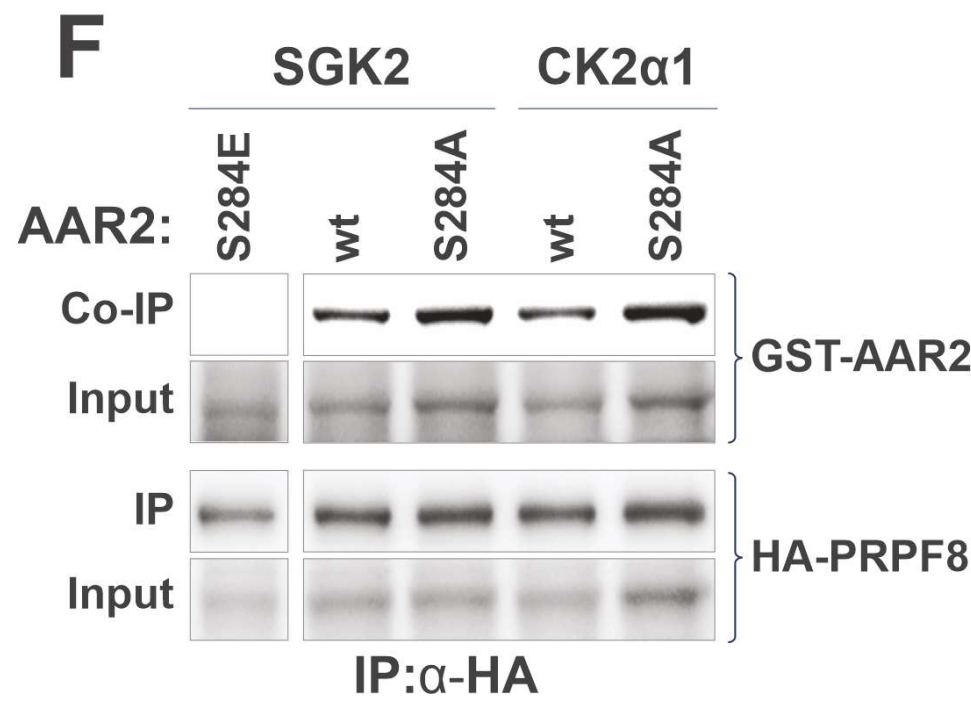


A

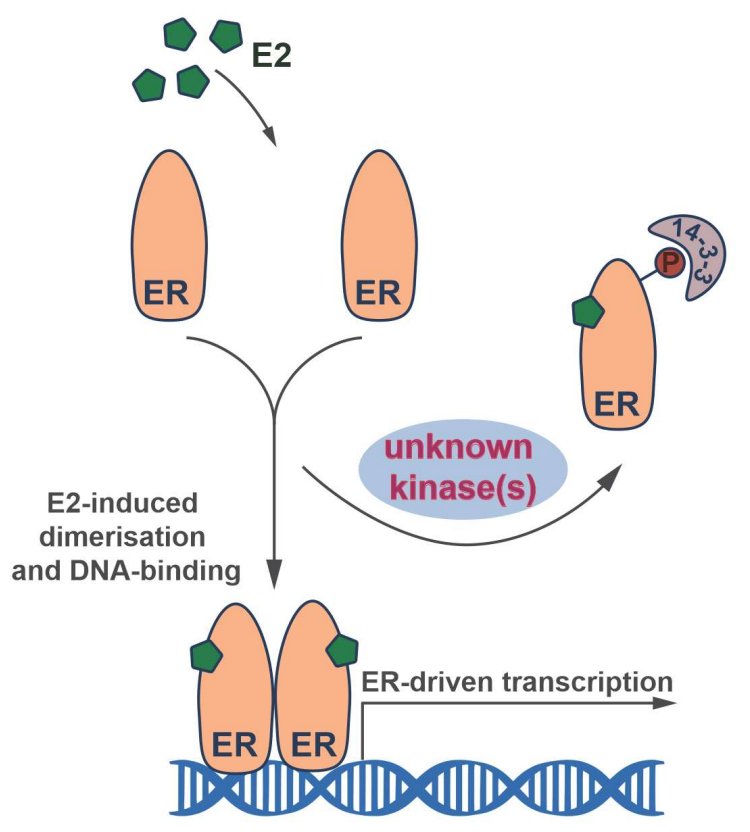

B

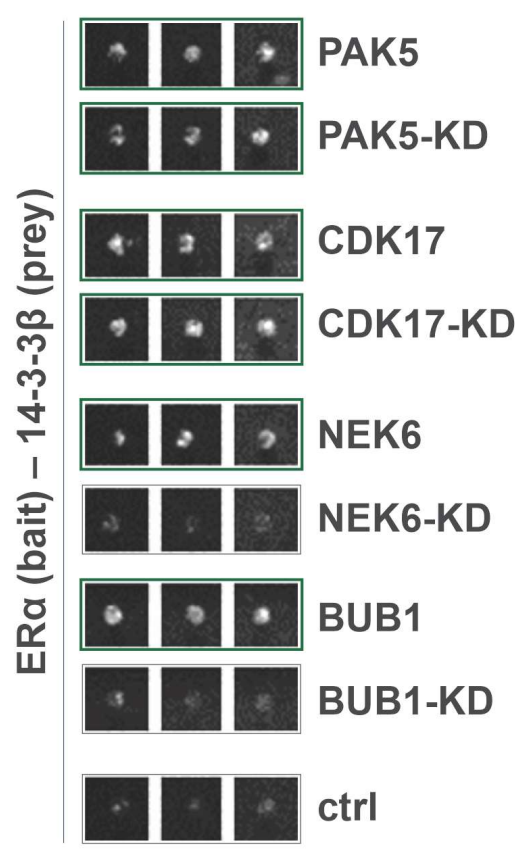

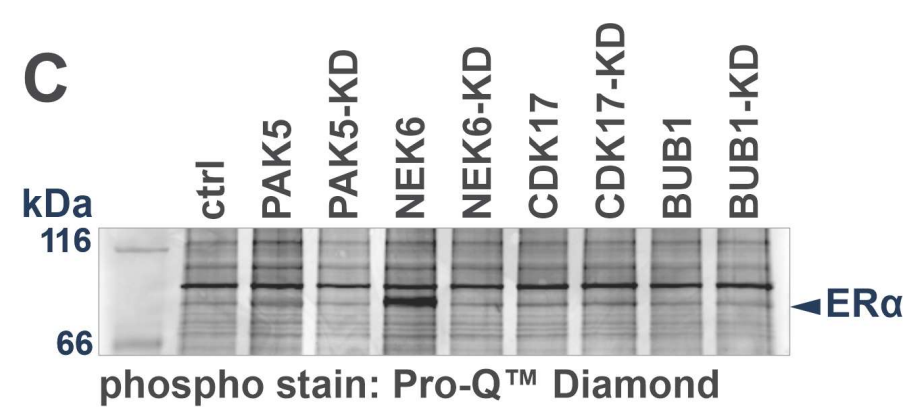

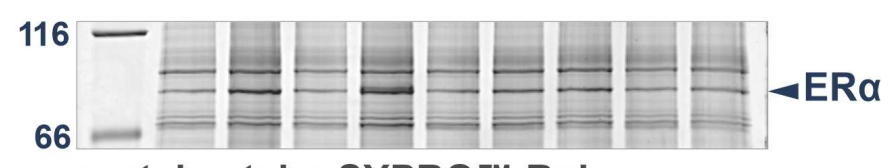
protein stain: SYPRO ${ }^{\text {TM }}$ Ruby

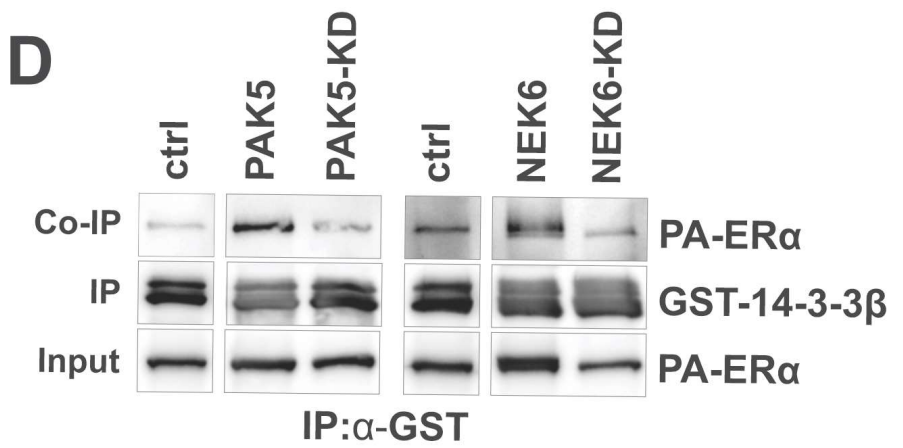

E

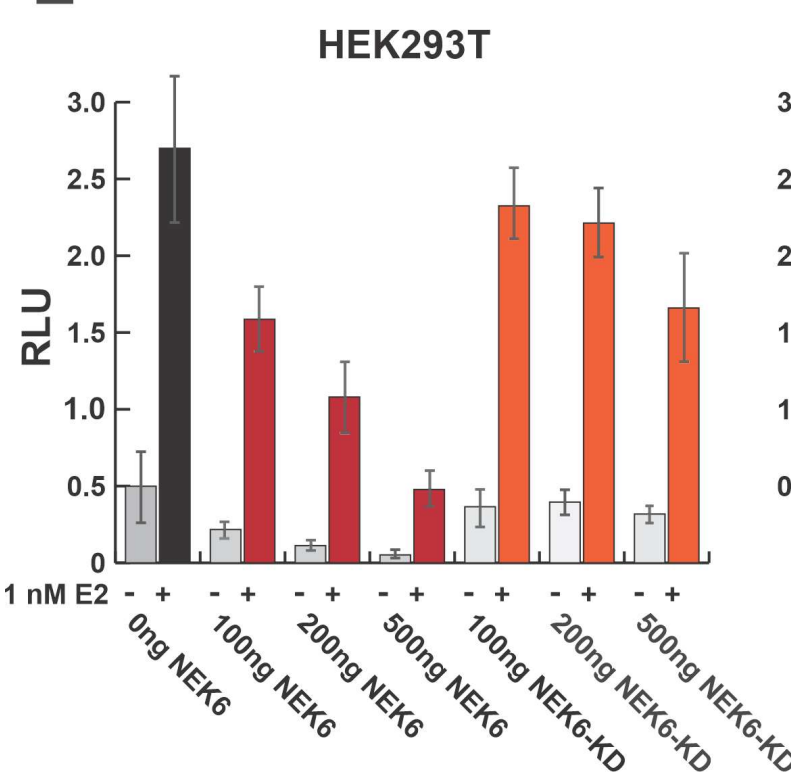

MCF-7

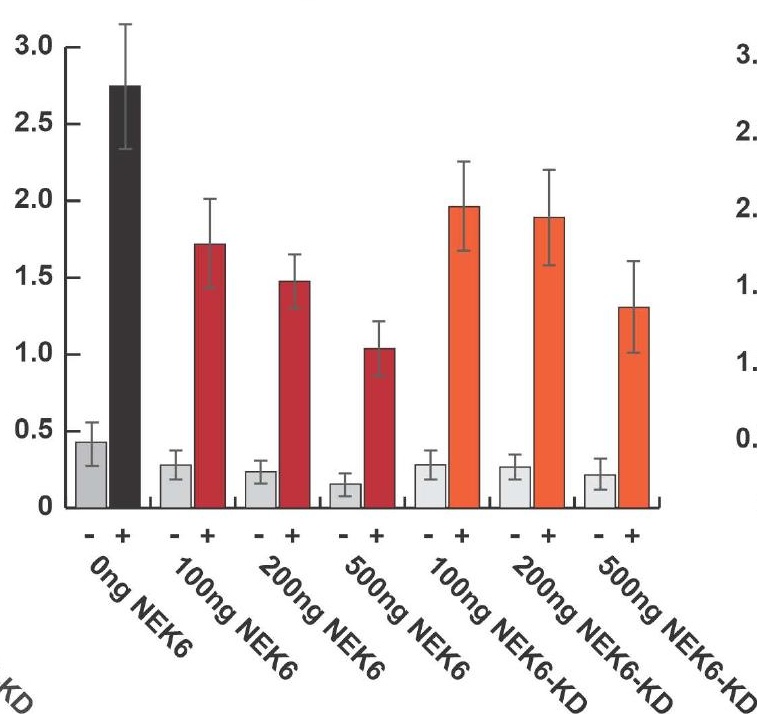

U2-OS
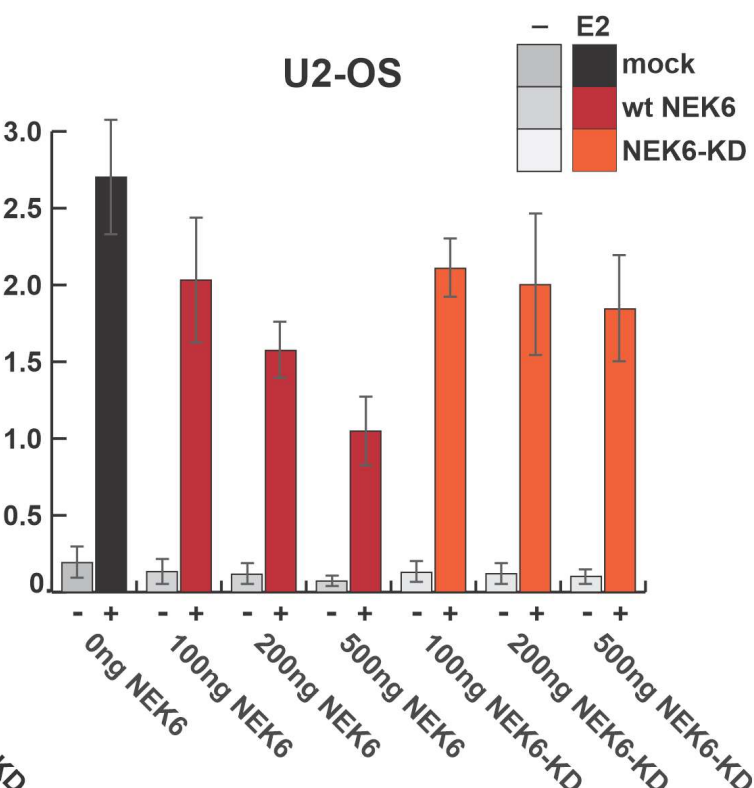


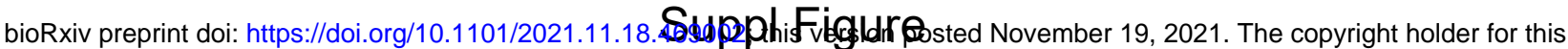
preprint (which was not certified by peer review) is the author/funder, who has granted bioRxiv a license to display the preprint in perpetuity. It is made available under aCC-BY-NC 4.0 International license.

\section{Supplementary Figure to Figure 6B}

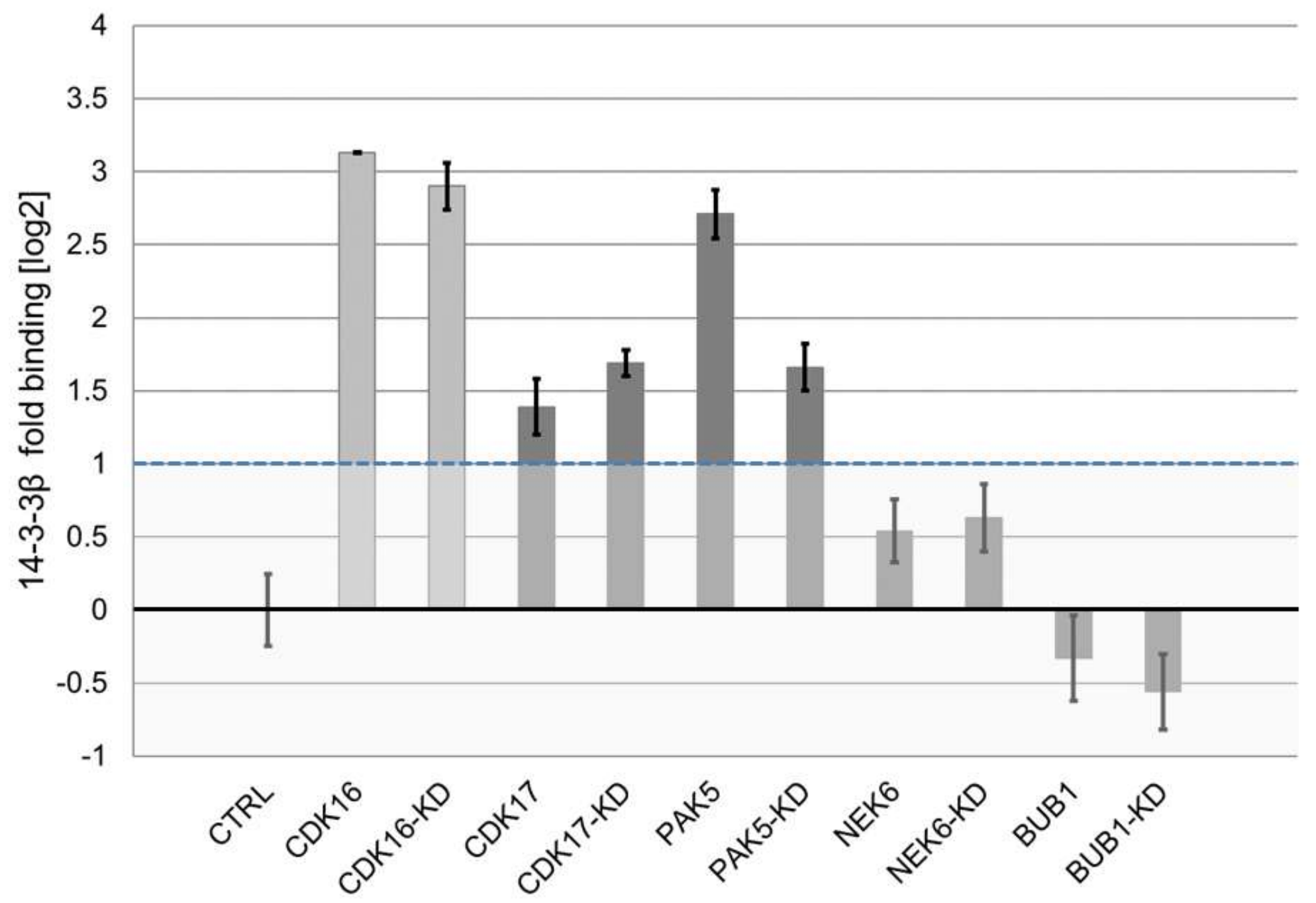

